\title{
Brown carbon: a significant atmospheric absorber of solar radiation?
}

\author{
Y. Feng ${ }^{1}$, V. Ramanathan ${ }^{2}$, and V. R. Kotamarthi ${ }^{1}$ \\ ${ }^{1}$ Environmental Science Division, Argonne National Laboratory, Argonne, IL 60439, USA \\ ${ }^{2}$ Center for Cloud, Chemistry and Climate, Scripps Institution of Oceanography, \\ University of California, San Diego, La Jolla, CA 92093, USA
}

Correspondence to: Y. Feng (yfeng@anl.gov)

Received: 10 January 2013 - Published in Atmos. Chem. Phys. Discuss.: 25 January 2013 Revised: 25 June 2013 - Accepted: 23 July 2013 - Published: 2 September 2013

\begin{abstract}
Several recent observational studies have shown organic carbon aerosols to be a significant source of absorption of solar radiation. The absorbing part of organic aerosols is referred to as "brown" carbon (BrC). Using a global chemical transport model and a radiative transfer model, we estimate for the first time the enhanced absorption of solar radiation due to $\mathrm{BrC}$ in a global model. The simulated wavelength dependence of aerosol absorption, as measured by the absorption Ångström exponent (AAE), increases from 0.9 for non-absorbing organic carbon to 1.2 (1.0) for strongly (moderately) absorbing BrC. The calculated AAE for the strongly absorbing BrC agrees with AERONET spectral observations at $440-870 \mathrm{~nm}$ over most regions but overpredicts for the biomass burning-dominated South America and southern Africa, in which the inclusion of moderately absorbing BrC has better agreement. The resulting aerosol absorption optical depth increases by $18 \%(3 \%)$ at $550 \mathrm{~nm}$ and $56 \%(38 \%)$ at $380 \mathrm{~nm}$ for strongly (moderately) absorbing $\mathrm{BrC}$. The global simulations suggest that the strongly absorbing $\mathrm{BrC}$ contributes up to $+0.25 \mathrm{~W} \mathrm{~m}^{-2}$ or $19 \%$ of the absorption by anthropogenic aerosols, while $72 \%$ is attributed to black carbon, and $9 \%$ is due to sulfate and nonabsorbing organic aerosols coated on black carbon. Like black carbon, the absorption of $\mathrm{BrC}$ (moderately to strongly) inserts a warming effect at the top of the atmosphere (TOA) $\left(0.04\right.$ to $\left.0.11 \mathrm{~W} \mathrm{~m}^{-2}\right)$, while the effect at the surface is a reduction $\left(-0.06\right.$ to $\left.-0.14 \mathrm{~W} \mathrm{~m}^{-2}\right)$. Inclusion of the strongly absorption of $\mathrm{BrC}$ in our model causes the direct radiative forcing (global mean) of organic carbon aerosols at the TOA to change from cooling $\left(-0.08 \mathrm{~W} \mathrm{~m}^{-2}\right)$ to warming $\left(+0.025 \mathrm{~W} \mathrm{~m}^{-2}\right)$. Over source regions and above clouds, the
\end{abstract}

absorption of $\mathrm{BrC}$ is higher and thus can play an important role in photochemistry and the hydrologic cycle.

\section{Introduction}

Absorption of solar radiation by aerosols has a significant impact on the atmospheric energy distribution and hydrologic processes. By intercepting incoming solar radiation before it reaches the surface, aerosols heat the atmosphere and, in turn, cool the surface. Locally, this leads to reduction in cloud cover through evaporation and suppression of the upward motion for cloud formation; on larger scales, surface dimming due to strong aerosol absorption could decrease global mean evaporation and rainfall by weakening the radiativeconvective coupling between the atmosphere and the surface (Ramanathan and Carmichael, 2008). The magnitude of the atmospheric forcing induced by anthropogenic absorbing aerosols, mainly black carbon (BC) emitted from combustion processes, has been suggested (Forster et al., 2007; Ramanathan and Carmichael, 2008) to be comparable to the atmospheric forcing by all greenhouse gases (GHGs). In addition to $\mathrm{BC}$, mineral dust particles also absorb in the solar radiation spectrum. Although absorbing aerosols amplify the atmospheric forcing due to GHGs, their dimming effect may compensate for or enhance the GHG warming at the surface, depending on vertical placement in the atmosphere (Penner et al., 2003). The short lifetimes of aerosols result in large variabilities in global and regional forcing. The significance and complexity of the climate impacts of absorbing 
aerosols highlight the importance of quantifying their radiative effects.

Model-simulated BC concentrations and aerosol absorption optical depth (AAOD) have been compared with surface and aircraft measurements such as the IMPROVE network (http://vista.cira.colostate.edu/improve), AERONET (Holben et al., 1998), and OMI satellite data (Torres et al., 2007). The model-data comparisons suggest that simulated BC surface concentrations, column loadings, and aerosol absorption are often underestimated over regions. Model underestimation can reach factors of 2 to 5 , particularly over regions dominated by biomass burning, South and East Asia, and remote regions (Koch et al., 2009; Menon et al., 2010; Ganguly et al., 2012). Such large gaps between simulated and observed BC and aerosol absorption lead to disconcerting discrepancies in the estimated aerosol radiative forcing. Two earlier observationally constrained approaches inferred a global BC forcing of about 0.9 to $1.0 \mathrm{~W} \mathrm{~m}^{-2}$ (Sato et al., 2003; Ramanathan and Carmichael, 2008). A more recent observational study by Chung et al. (2012) estimated a BC forcing of $0.65(0.5$ to 0.8$) \mathrm{W} \mathrm{m}^{-2}$, about $85 \%$ larger than the Intergovernmental Panel on Climate Change (IPCC) model estimate of 0.35 (0.2 to 0.6$) \mathrm{W} \mathrm{m}^{-2}$ (Forster et al., 2007), and $30 \%$ larger than post-IPCC model study results (Jacobson, 2010; Andrews et al., 2010; Ming et al., 2010; Shindell et al., 2012), which are closer to $0.5( \pm 0.05) \mathrm{W} \mathrm{m}^{-2}$. The direct absorption of sunlight by organic aerosols is typically ignored, except in a few studies (e.g., Jacobson, 2001).

Recently, optical and thermal analysis (e.g., Kirchstetter et al., 2004; Chen and Bond, 2010) and electron microscopy (e.g., Alexander et al., 2008) from laboratory and field experiments have provided strong evidence for the existence of some organic carbon (OC) with light absorbing properties. This fraction of absorbing $\mathrm{OC}$, known as brown carbon $(\mathrm{BrC})$ for its light brownish color, absorbs strongly in the ultraviolet wavelengths and less significantly going into the visible (Kirchstetter et al., 2004; Hoffer et al., 2006). Types of $\mathrm{BrC}$ include tar materials from smoldering fires or solid fuel combustion (Bond, 2001; Alexander et al., 2008), pyrolysis products from biomass burning (Mukai and Ambe, 1986), or humic-like substances from soil or biogenic emissions (Limbeck et al., 2003). Depending on its origins, the absorption efficiency and spectral dependence of $\mathrm{BrC}$ varies (Andreae and Gelencsér, 2006). A few recent observationally based studies indicated an abundance of $\mathrm{BrC}$ in the atmosphere, which could enhance solar radiation absorption and reduce surface radiative flux substantially (Chung et al., 2012; Bahadur et al., 2012). From the AERONET refractive index retrievals, Arola et al. (2011) inferred significant amounts of BrC (10-35 $\left.\mathrm{mg} \mathrm{m}^{-2}\right)$ in Africa, South America, and South and East Asia. Park et al. (2010) used a 1:1 mass ratio for $\mathrm{BC}$ to approximate $\mathrm{BrC}$ concentrations over East Asia and derived values for regional-mean radiative forcing of $\mathrm{BrC}$ of about $-0.43 \mathrm{~W} \mathrm{~m}^{-2}$ at the surface and $0.05 \mathrm{~W} \mathrm{~m}^{-2}$ at the top of the atmosphere (TOA).
However, in many global climate models, organic compounds are still considered mainly as scattering aerosols. Their optical properties are approximated by either nonabsorbing ammonium sulfate or weakly absorbing watersoluble aerosols (d'Almeida et al., 1991). Using a global chemical transfer model and a Monte Carlo radiative transport model, we examine the enhancement in atmospheric absorption due to $\mathrm{BrC}$ for year 2000 aerosol emissions and present the first global estimate of its direct perturbation on aerosol radiative forcing. The following section describes the global chemical transport model and a treatment for $\mathrm{BrC}$ optical properties. Section 3 compares the global calculations of aerosol optical properties with available surface and satellite observations and discusses the contribution of $\mathrm{BrC}$ absorption to aerosol direct radiative forcing. Finally, the main results of this study and implications for future work are summarized in Sect. 4.

\section{Model description}

\subsection{Global chemical transport model}

Global distributions of aerosol concentrations were simulated with a chemical transport model - a University of Michigan version of the Lawrence Livermore National Laboratory IMPACT model (Liu and Penner, 2002; Rotman et al., 2004; Liu et al., 2005). The global model has a horizontal resolution of $2^{\circ} \times 2.5^{\circ}$, with 26 vertical layers from the surface to the TOA. Tracers are transported at a $1 \mathrm{~h}$ time step. The transport schemes and aerosol modules were fully described by Rotman et al. (2004) and Liu et al. (2005), while nitrate and ammonium aerosols were included later (Feng and Penner, 2007). We adopted a version of the IMPACT model used by Feng and Ramanathan (2010), which is coupled with the European Centre for Medium-Range Weather Forecasts $40 \mathrm{yr}$ re-analysis (ERA-40) meteorological data fields for year 2001 (Uppala et al., 2005). The treatment for aerosols is summarized below, while other model physics are given in the Appendix.

In the IMPACT model, sulfate aerosol is represented in three size bins of radius $<0.05 \mu \mathrm{m}, 0.05-0.63 \mu \mathrm{m}$, and $0.63-1.26 \mu \mathrm{m}$. The concentrations of $\mathrm{SO}_{2}, \mathrm{SO}_{4}^{2-}, \mathrm{H}_{2} \mathrm{O}_{2}$, and dimethyl sulfide (DMS) were simulated with an online sulfur model (Liu and Penner, 2002; Liu et al., 2005). As indicated by Liu et al. (2007), gas-phase-produced sulfate mass was distributed to the three size bins on the basis of a continental sulfate aerosol size distribution (Chuang et al., 1997), and the sulfate produced in cloud was added to the second size bin as accumulation-mode aerosol. The size-segregated mass fluxes for sea salt and dust were calculated as dependent on wind speed, according to Monahan et al. (1986) and Ginoux et al. (2001), respectively. Once emitted, sea salt and mineral dust aerosols were transported in four different sized bins (0.05-0.63 $\mu \mathrm{m}, 0.63-1.26 \mu \mathrm{m}, 1.26-2.5 \mu \mathrm{m}$, and 2.5-10 $\mu \mathrm{m})$. 
Table 1. Annual emissions and burdens of anthropogenic aerosols and their lifetimes, simulated for year $2000^{1}$.

\begin{tabular}{|c|c|c|c|c|}
\hline & Sulfate & Black carbon & Organic matter & $\begin{array}{l}\text { Brown } \\
\text { carbon }\end{array}$ \\
\hline Total emissions & $96.14 \mathrm{Tg} \mathrm{S}$ & $7.96 \mathrm{Tg} \mathrm{C}$ & $69.5 \mathrm{Tg}$ & - \\
\hline Sources & $\begin{array}{l}\text { FF: } 56.2 \\
\text { Volcanoes: } 14.6 \\
\text { DMS: } 25.3\end{array}$ & $\begin{array}{l}\text { FF: } 3.15 \\
\text { BF: } 1.77 \\
\text { BB: } 3.04\end{array}$ & $\begin{array}{l}\text { FF: } 4.5 \\
\text { BF: } 11.2 \\
\text { BB: } 34.7 \\
\text { Natural: } 19.1\end{array}$ & - \\
\hline $\begin{array}{l}\text { Burden, } \mathrm{mg} \mathrm{m}^{-2} \\
\text { (AeroCom estimates) }^{2}\end{array}$ & $\begin{array}{l}4.7 \\
\text { (mean: } 4.9 \\
\text { min: } 1.8 \\
\text { max: } 5.3 \text { ) }\end{array}$ & $\begin{array}{l}0.19 \\
\text { (mean: } 0.39 \\
\text { min: } 0.09 \\
\max : 1.0 \text { ) }\end{array}$ & $\begin{array}{l}1.5 \\
\text { (mean: } 3.3 \\
\text { min: } 0.9 \\
\text { max: } 5.0 \text { ) }\end{array}$ & 0.65 \\
\hline Lifetime: days & 3.04 & 4.45 & 4.02 & - \\
\hline
\end{tabular}

Carbonaceous aerosols, $\mathrm{BC}$ and $\mathrm{OC}$ were each transported in a single submicron size bin (radius $<0.63 \mu \mathrm{m}$ ).

The content of $\mathrm{BrC}$ in $\mathrm{OC}$ generated from biofuel combustion and biomass burning sources is approximated to be $92 \%$, for methanol-soluble absorbing OC, on the basis of a solid-fuel pyrolysis study (Chen and Bond, 2010). Organic solvents can dissolve most of the absorbing organics, including water-soluble OCs (Chen and Bond, 2010). In the IMPACT model, the conversion factor between OC and particulate organic matter is $1: 1.4$ (Liu et al., 2005), which accounts for the non-carbon mass and secondary aerosol formation from volatile organic compounds. Therefore, the fractional $\mathrm{BrC}$ in total organic matter from biofuel and biomass emissions is approximately $66 \%(=92 \% / 1.4)$. The remaining $34 \%$ of the simulated organic matter mass is assumed to be non-absorbing or scattering only. We assume $0 \% \mathrm{BrC}$ in the primary emissions of fossil fuel-produced organic matter, as the high-temperature environment generally associated with fossil fuel combustion is unfavorable for the formation of BrC (Andreae and Gelencsér, 2006). This assumption is consistent with the results of observationally based studies, in which $\mathrm{BrC}$ is inferred to be most abundant over regions dominated by biofuel combustion or biomass burning (Arola et al., 2011). Naturally emitted OC might also be a source of primary $\mathrm{BrC}$ particles (Andreae and Gelencsér, 2006). We do not consider these emissions due to the level of uncertainty in these estimates.

Table 1 summarizes annual emissions and burdens of major aerosols and their lifetimes, calculated for year 2000. Anthropogenic $\mathrm{SO}_{2}$ emissions are based on the EDGARv32 emission inventory (Olivier et al., 2001; Olivier and Berdowski, 2001). The gridded $\mathrm{SO}_{2}$ is scaled by the ratio of the AeroCom global emission (Dentener et al., 2006) over that of EDGAR, for a total of $56.24 \mathrm{Tg}$ S. Additional emissions of $\mathrm{SO}_{2}$ include non-eruptive volcanoes (Dentener et al., 2006) and an oceanic DMS source (Kettle and Andreae, 2000). The fossil fuel and biofuel emissions of BC and OC are from Bond et al. (2007). The BC and OC from open biomass burning and naturally emitted $\mathrm{OC}$ are based on AeroCom emissions (Dentener et al., 2006). Total emissions of $\mathrm{BC}(7.96 \mathrm{TgC})$ and organic matter emissions $(69.5 \mathrm{Tg})$ in this study are comparable to the AeroCom emissions (7.72 Tg BC; $67.5 \mathrm{Tg}$ organic matter). As Table 1 shows, the model-calculated aerosol burdens are in the ranges of the AeroCom model predictions for year 2000 (Kinne et al., 2006). In addition, the global burden of $\mathrm{BrC}$ aerosols is estimated to be $0.65 \mathrm{mg} \mathrm{m}^{-2}$, more than three times the $\mathrm{BC}$ content $\left(0.19 \mathrm{mg} \mathrm{m}^{-2}\right)$ in the atmosphere. The geographic distributions of simulated $\mathrm{BrC}$ burden and the fractions $\mathrm{BrC} / \mathrm{OC}$ and $\mathrm{BrC} / \mathrm{BC}$ are shown in Fig. 1. Over the major biomass burning and biofuel combustion regions, the annual mean $\mathrm{BrC}$ loadings generally exceed $2 \mathrm{mg} \mathrm{m}^{-2}$, and the fraction of $\mathrm{BrC}$ in total OC is high, above $40-50 \%$. The highest BrC burden of about $15-20 \mathrm{mg} \mathrm{m}^{-2}$ is in southern Africa, where the $\mathrm{BrC}$ fraction in $\mathrm{OC}$ is also the largest at over $70-80 \%$. The content of $\mathrm{BrC}$ in total organic aerosols is low, at 20 $40 \%$, in fossil-fuel-dominated eastern North America, Western Europe, and East Asia, as well as in major natural organic source regions in South America and Southeast Asia. The ratio of $\mathrm{BrC}$ to $\mathrm{BC}$ is generally higher in the Southern Hemisphere $(>6)$ than in the Northern Hemisphere $(<2)$, suggesting a possibly larger impact of $\mathrm{BrC}$ on aerosol absorption of solar radiation in the cleaner Southern Hemisphere.

\subsection{Optical properties of brown carbon}

Aerosol optical properties (specific extinction, singlescattering albedo [SSA], and asymmetry factor) are calculated from the Mie theory (Bohren and Huffman, 1983), assuming spherical particles. Here two sets of refractive index values for $\mathrm{BrC}$ are derived to match the observed absorption 
(a)

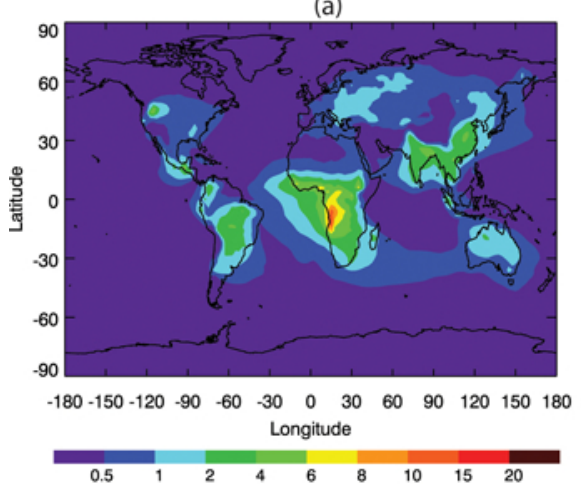

(b)

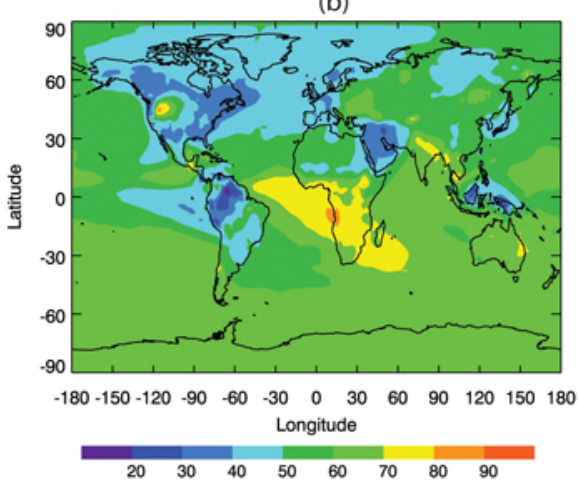

(c)

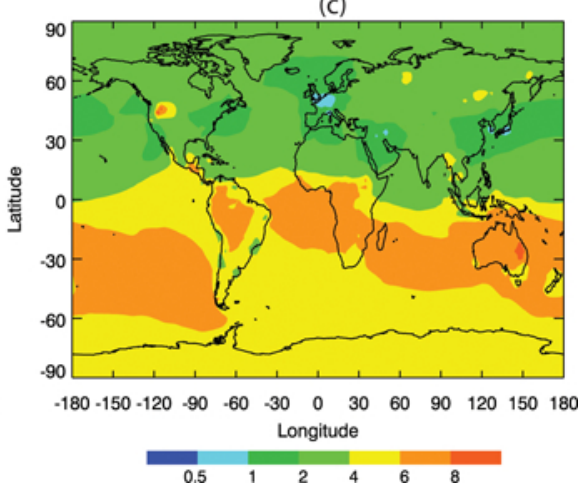

Fig. 1. The estimated (a) annual mean atmospheric burden $\left(\mathrm{mg} \mathrm{m}^{2}\right)$ of $\mathrm{BrC},(\mathbf{b})$ percentage $(\%)$ of $\mathrm{BrC}$ in total $\mathrm{OC}$, and (c) ratio of $\mathrm{BrC}$ to BC.

Table 2. The imaginary refractive index, absorption cross section, and absorption Ångström exponent (AAE) calculated for brown carbon $(\mathrm{BrC})$ at various wavelengths, compared with those from Chen and Bond (2010) and Kirchstetter et al. (2004).

\begin{tabular}{lllll|lllll|l}
\hline & \multicolumn{3}{c|}{$\begin{array}{l}\text { Imaginary refractive index } \\
\text { at indicated wavelength }\end{array}$} & \multicolumn{3}{l|}{$\begin{array}{l}\text { Absorption cross section at indicated } \\
\text { wavelength }\left(\mathrm{m}^{2} \mathrm{~g}-1\right)\end{array}$} & AAE \\
\hline Wavelength $\lambda(\mathrm{nm})$ & 350 & 450 & 550 & 650 & 350 & 450 & 550 & 650 & $400-700$ \\
Moderately absorbing BrC & 0.075 & 0.02 & 0.003 & 0.0003 & 2.25 & 0.63 & 0.08 & 0.006 & 11.1 \\
Strongly absorbing BrC & 0.168 & 0.063 & 0.03 & 0.005 & 3.4 & 1.6 & 0.7 & 0.1 & 6.6 \\
Chen and Bond (2010)* & 0.1 & 0.02 & 0.006 & $1 \times 10^{-4}$ & 2.25 & 0.4 & 0.08 & 0.001 & 7.5 \\
Kirchstetter et al. (2004) & 0.168 & 0.063 & 0.03 & 0.005 & 5.0 & 1.5 & 0.6 & 0.1 & - \\
\hline
\end{tabular}

* The absorption cross sections shown are for methanol-soluble OAK_L_360 in Chen and Bond (2010); refractive index is derived based on $\rho \lambda \sigma / 4 \pi$, where $\rho$ is the density of $\mathrm{BrC}, 1.65 \mathrm{~g} \mathrm{~cm}^{-3}$.

cross sections - at $550 \mathrm{~nm}, 0.08 \mathrm{~m}^{2} \mathrm{~g}^{-1}$ for the moderately absorbing BrC (Chen and Bond, 2010) and $\sim 0.7 \mathrm{~m}^{2} \mathrm{~g}^{-1}$ for the strongly absorbing BrC (Kirchstetter et al., 2004). Table 2 compares the values calculated in this study for absorption cross section $\left(\mathrm{m}^{2} \mathrm{~g}^{-1}\right)$ and the imaginary refractive index at 350-650 nm with those of Chen and Bond (2010) and Kirchstetter et al. (2004). In the Mie calculations, the density of $\mathrm{BrC}$ is $1.569 \mathrm{~g} \mathrm{~cm}^{-3}$, and the real part of its refractive index is 1.65 (Hoffer et al., 2006). A typical size distribution of fuel combustion aerosols is used, with a mean diameter of $100 \mathrm{~nm}$ and standard deviation of 1.5 (Bond and Bergstrom, 2006). For the optical properties of $\mathrm{BrC}$ listed in Table 2, the absorption Ångström exponent (AAE), defined as

$\operatorname{AAOD}(\lambda) \sim \lambda^{-\mathrm{AAE}}$,

is 11 for moderately absorbing $\mathrm{BrC}$ and 6.6 for strongly absorbing $\mathrm{BrC}$ between $400-700 \mathrm{~nm}$. The wavelength $\lambda$ is in $\mathrm{nm}$. This calculated spectral dependence of aerosol absorption is consistent with that observed for $\mathrm{BrC}$ (Kirchstetter and Thatcher, 2012). The differences in the derived refractive indices and absorption cross section from Kirchstetter et al. (2004) and Chen and Bond (2010) are due to different size distributions and/or densities used in our Mie calculations.

The refractive indices for other aerosol species are the same as in Feng and Ramanathan (2010). To account for enhanced absorption of carbonaceous particles due to coating acquired in the aging process, a core-shell configuration (Bohren and Huffman, 1983) is implemented in the calculation of optical properties for fossil fuel, biofuel, and biomass burning aerosols. The core is assumed to be strongly absorbing $\mathrm{BC}$ with a refractive index of $1.8+i 0.74$ (Bond and Bergstrom, 2006). The outer shell consists of non-absorbing sulfate and $\mathrm{OC}$ for fossil fuel aerosols, versus absorbing $\mathrm{BrC}$ and/or non-absorbing OC for biofuel and biomass burning aerosols, respectively. This core-shell configuration represents the likely aerosol mixtures on the basis of their origins, because of a lack of information on the aerosol mixing state given by the global model. Mie calculations were performed offline for a number of $\mathrm{BC}, \mathrm{OC}, \mathrm{BrC}$, and sulfate mixtures and relative humidity $(\mathrm{RH})$ values; a lookup table was generated and used in the global calculations presented in the next section. Climatological aerosol size distributions are used for fossil fuel sulfate/BC/OC and biofuel BC/OC aerosols (Radke et al., 1988, mean diameter $100 \mathrm{~nm}$ and standard deviation $=1.9$ ) and for biomass burning BC/OC aerosols (Anderson et al., 1996, mean diameter $160 \mathrm{~nm}$ and standard deviation $=1.65$ ), according to Liu et al. (2007) and Penner et al. (2001). Dust, sea salt, and naturally emitted non-absorbing organic matter are assumed to be mixed externally. 


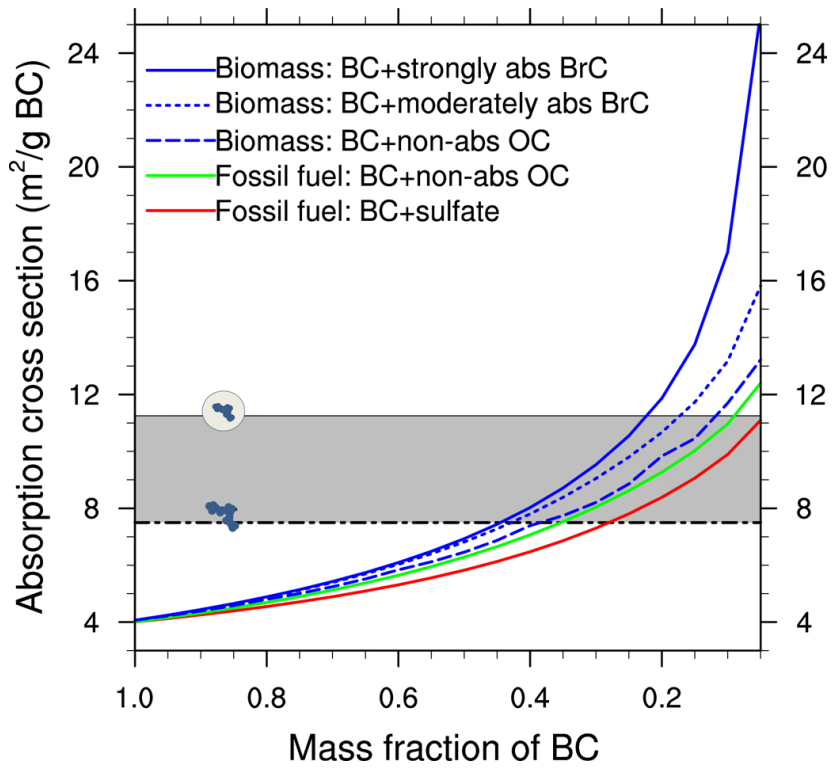

Fig. 2. The enhancement in absorption cross section $\left(\mathrm{m}^{2} \mathrm{~g}^{-1} \mathrm{BC}\right)$ at $550 \mathrm{~nm}$, calculated for coated BC particles in dry conditions. The composition of the coating material is assumed to be sulfate (red) or non-absorbing OC (green) for fossil fuel aerosol. For biofuel and biomass burning aerosols the coating is non-absorbing OC (blue dashed), or moderately absorbing BrC (blue dotted), or strongly absorbing $\mathrm{BrC}$ (blue solid). Also shown in gray shading are values for BC aggregates $\left(7.5 \mathrm{~m}^{2} \mathrm{~g}^{-1}\right)$ and aged BC with coatings $\left(11.25 \mathrm{~m}^{2} \mathrm{~g}^{-1}\right)$ recommended by Bond and Bergstrom (2006) and Bond et al. (2006).

Figure 2 shows the calculated absorption cross section $\left(\mathrm{m}^{2} \mathrm{~g}^{-1} \mathrm{BC}\right)$ at $550 \mathrm{~nm}$ for dry absorbing aerosols by source. Because source-based aerosol size distributions are prescribed and do not change in the IMPACT model, a decrease of $\mathrm{BC}$ mass fraction in the aerosol mixture indicates thicker coatings on smaller BC cores. The simulated enhancement in absorption as a function of the decreased $\mathrm{BC}$ mass fraction in Fig. 2 reflects not only the coating effect from increasing shell substances but also from the size reduction of $\mathrm{BC}$ particles as core. Thus, these curves may not be used for direct comparison with the lensing effect for coating on $\mathrm{BC}$ particles of constant size. For the same shell thickness, the enhancement introduced by $\mathrm{BrC}$ coatings is larger than those for sulfate or non-absorbing OC as expected. However, for hygroscopic sulfate, the enhancement effect could be amplified further by water uptake. For example, at $\mathrm{RH}=$ $80 \%$, an absorption cross section with a mass ratio of $4: 1$ for sulfate : $\mathrm{BC}$ is estimated at about $9.1 \mathrm{~m}^{2} \mathrm{~g}^{-1} \mathrm{BC}$, versus $8.4 \mathrm{~m}^{2} \mathrm{~g}^{-1} \mathrm{BC}$ at $\mathrm{RH}=0 \%$.

Bond and Bergstrom (2006) and Bond et al. (2006) suggested that lower bounds of absorption are $5 \mathrm{~m}^{2} \mathrm{~g}^{-1}$ for submicron collapsed BC particles and $7.5 \mathrm{~m}^{2} \mathrm{~g}^{-1}$ for freshly emitted aggregates. They also indicated that simple aerosol models might improve aerosol optics by as- suming that absorption increases linearly as non-absorbing aerosol condenses, reaching a maximum 1.5 times greater (i.e., $7.5 \mathrm{~m}^{2} \mathrm{~g}^{-1}$ times $1.5=11.25 \mathrm{~m}^{2} \mathrm{~g}^{-1}$ ) when particle volume has increased up to a factor of about six. Compared with their recommended absorption cross section (7.5 to $11.25 \mathrm{~m}^{2} \mathrm{~g}^{-1}$ ) for $\mathrm{BC}$ coated with non-absorbing material (gray shaded areas in Fig. 2), the calculated absorption cross sections for sulfate and non-absorbing OC coatings are similar when the mass fraction of $\mathrm{BC}$ in aerosol is lower than approximately 0.3-0.4. As illustrated in Sect. 3.2, the mass ratios of $\mathrm{OC}: \mathrm{BC}$ simulated by our global model are $>1.5$ on an annual mean basis; correspondingly, the mass fractions of $\mathrm{BC}$ in aerosol mixtures are indeed $<0.4$. As most of the simulated $\mathrm{BC}$ mass ratios range from 0.4 to 0.1 with an $\mathrm{OC}: \mathrm{BC}$ ratio of 1.5-10 (Sect. 3.2), the model calculations in Fig. 2 indicate that the inclusion of moderate or strong absorption by $\mathrm{BrC}$ leads to absorption cross sections $>8 \mathrm{~m}^{2} \mathrm{~g}^{-1} \mathrm{BC}$ (up to $16 \mathrm{~m}^{2} \mathrm{~g}^{-1} \mathrm{BC}$ ) for fossil fuel or biomass burning aerosols in global model simulations, given their climatological size distributions.

\section{Global results}

To investigate the impact of $\mathrm{BrC}$ absorption on aerosol forcing on a global scale, we conducted three global calculations of aerosol optical properties and radiative transfer, with nonabsorbing OC, moderately absorbing $\mathrm{BrC}$, and strongly absorbing $\mathrm{BrC}$. Model results from these three simulations are referred to hereafter as "NON", "MOD", and "STR". The control case - the NON case - is similar to most of the current global aerosol models that treat $\mathrm{OC}$ as scattering only. The sensitivity calculations for MOD and STR are used to estimate the low and high limits of the resulting aerosol forcing by converting a fraction of non-absorbing OC to absorbing $\mathrm{BrC}$.

\subsection{Aerosol optical depth and single-scattering albedo at $550 \mathrm{~nm}$}

The model-calculated annual mean aerosol optical depth (AOD) at $550 \mathrm{~nm}$ for the NON case is compared in Fig. 3 with the MODIS/Terra satellite observations (MOD08 Level 3) for year 2001. The global model calculations of AOD_NON approximate the observed aerosol hot spots identified by the local maximum in the MODIS AOD, such as eastern China (>0.5), northern India and the Arabian Sea (0.3-0.6), and north-central Africa (0.3-0.5). Agreement in AOD is also found in most of Europe and North America, where the prevailing annual mean AOD is low, at about 0.2. Both modeled and observed AOD values have similar spatial patterns over the ocean, ranging from 0.1 to 0.3 , with higher values in the high-wind regions (due to sea salt) or downwind from continental pollution. Compared with MODIS, the IMPACT model under-predicts in areas of south-central 
(a)

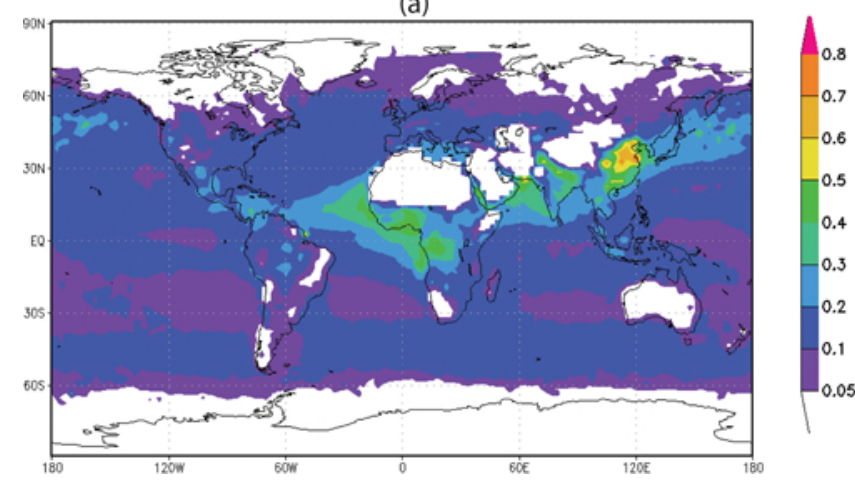

(b)

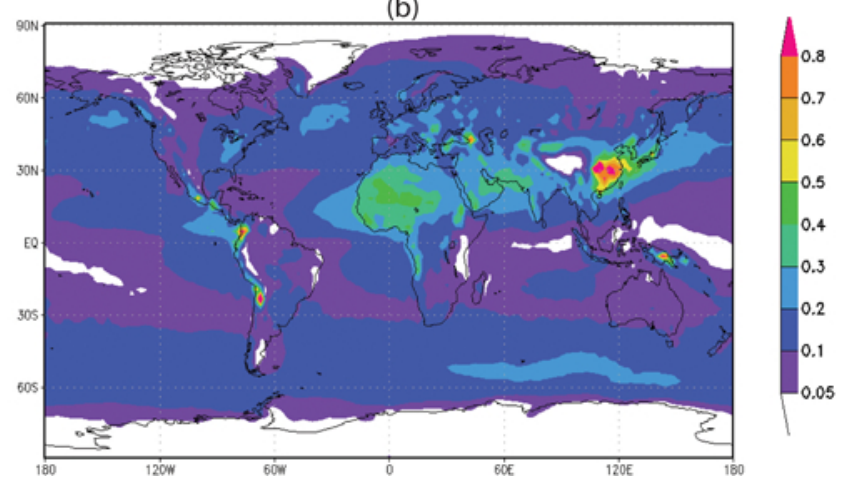

Fig. 3. Annual mean aerosol optical depth from (a) MODIS/Terra satellite observations (2001) and (b) model simulations with non-absorbing OC. The white color in panel (a) indicates areas over which satellite retrievals are not available.

Africa, Amazon forests, and South and East Asia dominated by biomass burning and over-predicts in volcano-influenced regions of South America and Indonesia. These model biases might be related to uncertainty in aerosol emissions, because most of the discrepancies occur near those source regions. The calculated global and annual mean AOD_NON is 0.132, within $3 \%$ of the MODIS retrieval (0.128). Similar values are calculated with both AOD_MOD and AOD_STR and are not shown here. This agreement between the model AOD and satellite observations helps to constrain the estimation of aerosol radiative forcing discussed in Sect. 3.2.

Figure 4 compares the monthly mean SSA at $550 \mathrm{~nm}$ from the model calculations (NON, MOD, and STR) and the AERONET data. The AERONET SSA values shown are calculated from the AERONET V2 Inversion products Level-2 daily data at $440 \mathrm{~nm}$ and $675 \mathrm{~nm}$ (Dubovik et al., 2006). Note that the Level-2 SSA retrievals may be biased for large AOD, as described in their quality assurance criteria (http://aeronet.gsfc.nasa.gov/new_web/data.html). For computation of the monthly means, we selected only the AERONET sites with at least 10 daily measurements for each month during the $20 \mathrm{yr}$ from 1992 to 2011 . The monthly predictions for SSA_NON correlate with the AERONET observations (a total of 1061 data points), with a calculated Pearson's correlation coefficient of 0.51 . The mean percentage error and bias between the modeled SSA_NON and observed SSA values are small, at about $-2 \%$ and $3 \%$, respectively.

Table 3 compares the calculated global and regional average SSA values at $550 \mathrm{~nm}$ from the three model simulations with AERONET data. Regionally, the model results for SSA_NON indicate that aerosols are generally more absorbing in biomass burning regions $(0.87-0.9)$ and South and East Asia $(\sim 0.93)$ than over Europe and North America $(\sim 0.95)$, similar to the AERONET data. In dust-influenced central Africa, however, the predicted mean SSA_NON is about 0.96, larger than the mean retrieval of 0.92 from AERONET.

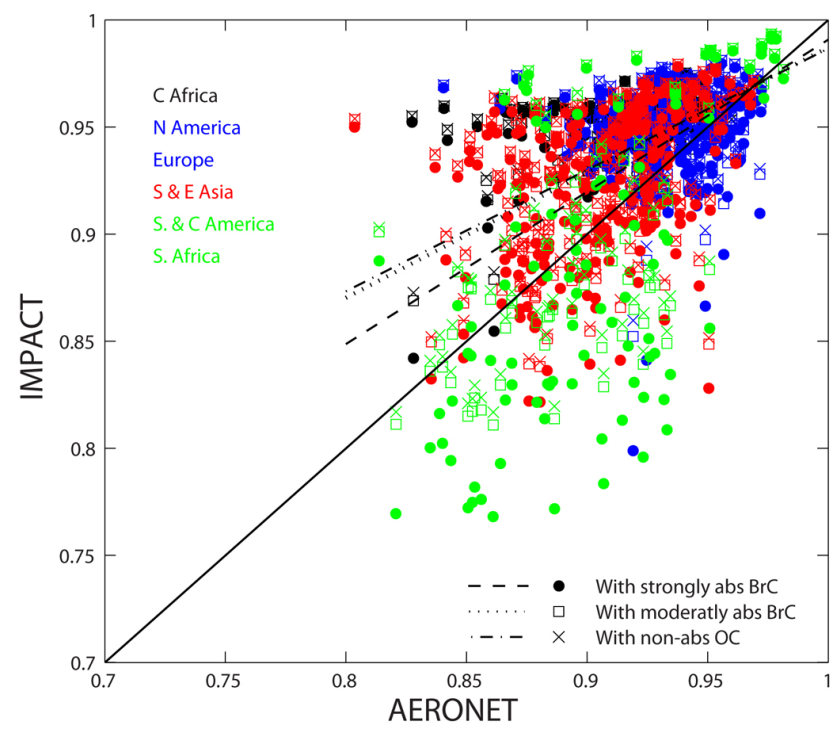

Fig. 4. Comparison of monthly mean SSA at $550 \mathrm{~nm}$ from AERONET (1992-2011) and three model simulations (NON, MOD, and STR). The solid line indicates the $1: 1$ ratio. Data points in central Africa (C. Africa), Europe and North America, South Asia and East Asia (S \& E Asia) and regions dominated by biomass burning (South and Central America (S \& C America) and southern Africa (S. Africa)) are colored in black, blue, red, and green, respectively. The linear fitting functions are $y=0.71 x+0.3$ for the STR BrC (dashed line; solid circles), $y=0.58 x+0.4$ for the MOD $\mathrm{BrC}$ (dotted line; open squares), and $y=0.57 x+0.42$ for the nonabsorbing OC (dash-dotted line; cross symbols).

\subsection{Effects of brown carbon on aerosol spectral absorption}

The consideration of $\mathrm{BrC}$ increases total aerosol absorption. In both Fig. 4 and Table 3, the SSA_STR (solid circles) and SSA_MOD (open squares) model simulations with BrC predict lower SSA values at $550 \mathrm{~nm}$ than does SSA_NON (cross symbols). Averaged over all AERONET sites, the SSA_STR 
Table 3. The calculated global and regional average single-scattering albedo (SSA) values at $550 \mathrm{~nm}$ from different model simulations, compared with AERONET data.

\begin{tabular}{llllll}
\hline & \multicolumn{5}{c}{ SSA at 550 nm } \\
\cline { 2 - 6 } & $\begin{array}{l}\text { N. America and } \\
\text { Europe }\end{array}$ & S. and E. Asia & C. Africa & $\begin{array}{l}\text { S. and C. America } \\
\text { and southern Africa }\end{array}$ & Global average \\
\hline Data points & 228 & & & 92 & $842^{*}$ \\
AERONET & $0.933 \pm 0.021$ & $0.912 \pm 0.03$ & $0.928 \pm 0.024$ & $0.899 \pm 0.041$ & $0.917 \pm 0.030$ \\
Without BrC & $0.953 \pm 0.017$ & $0.936 \pm 0.031$ & $0.957 \pm 0.011$ & $0.898 \pm 0.054$ & $0.940 \pm 0.033$ \\
MOD BrC & $0.952 \pm 0.017$ & $0.936 \pm 0.032$ & $0.957 \pm 0.011$ & $0.895 \pm 0.056$ & $0.939 \pm 0.034$ \\
STR BrC & $0.949 \pm 0.021$ & $0.932 \pm 0.035$ & $0.956 \pm 0.014$ & $0.871 \pm 0.070$ & $0.932 \pm 0.042$ \\
\hline
\end{tabular}

${ }^{*}$ In order to compare with the model results, a total of 1061 AERONET data points are averaged into 842 data points on model grid cells of $2^{\circ} \times 2.5^{\circ}$.

(a)

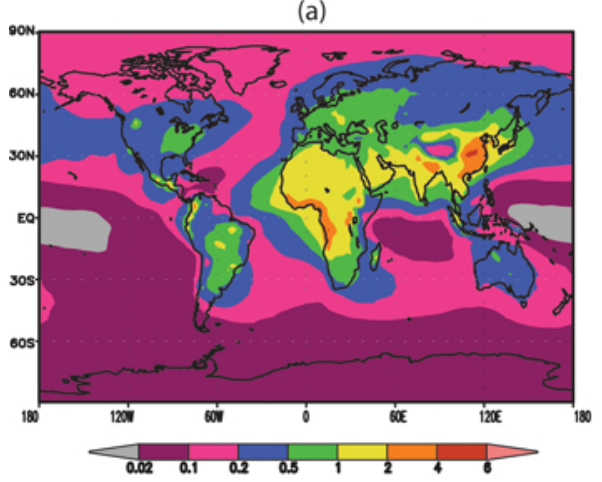

(b)

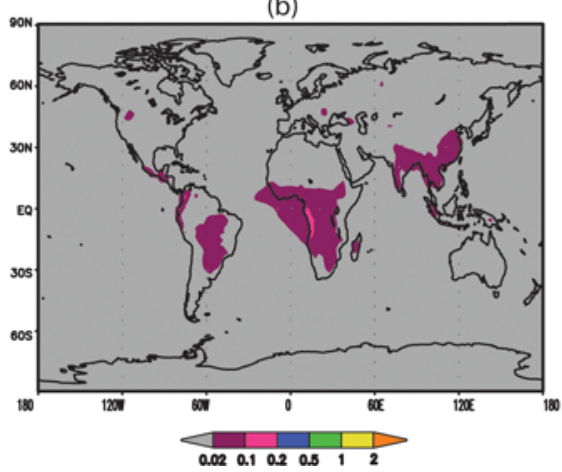

(c)

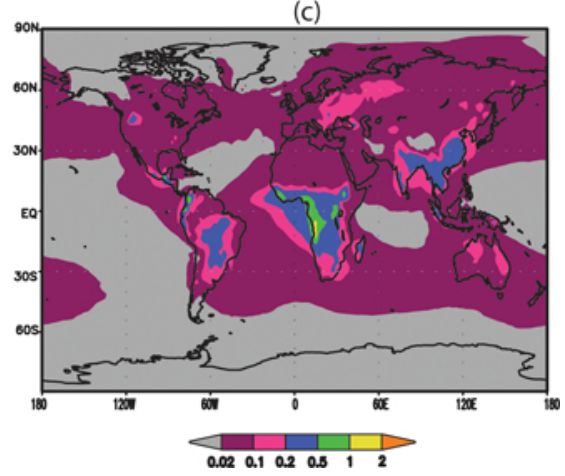

Fig. 5. (a) Annual mean absorption aerosol optical depth $(A A O D \times 100)$ calculated with the non-absorbing OC, with increases in $A A O D$ $(\times 100)$ due to the inclusion of the (b) MOD BrC and (c) STR BrC.

value (0.93) agrees slightly better with the observations (0.92) than do the SSA_MOD (0.94) and SSA_NON (0.94) values. In South and Central America and southern Africa, the best agreement is, however, for the non-absorbing OC case (SSA_NON $=0.9$ ), while the SSA_STR value $(0.87)$ is lower than the AERONET data (0.9) by $3 \%$. In addition to the refractive index/absorption cross section used for $\mathrm{BrC}$ in the STR case, the low-biased SSA_STR in the biomass burning region could be due to the assumed fraction of $\mathrm{BrC}$ in total OC (92\%, based on a solid fuel analysis) is too high for these sources. Nevertheless, the differences in SSA at $550 \mathrm{~nm}$ between the NON, MOD, and STR cases are at about 1-2\%.

The resulting enhancement in AAOD is illustrated in Fig. 5. The global and annual mean AAOD_NON $(\times 100)$ at $550 \mathrm{~nm}$ is increased by $18 \%$ for the AAOD_STR case, especially over biomass burning or biofuel combustion regions, where the AAOD simulated by large-scale models often underestimates the observations (Koch et al., 2009). In the Southern Hemisphere, the percent increase in AAOD_STR relative to AAOD_NON is about $20-40 \%$, more substantial than that obtained in the Northern Hemisphere, where absorbing aerosols of other types (BC and dust) are also abundant. On the other hand, originating mainly from biofuel consumption rather than open vegetation burning as in
Table 4. Global and annual mean aerosol absorption optical depth (AAOD) and absorption Ångström exponent (AAE) at various wavelengths. The percentage increase in AAOD with the inclusion of $\mathrm{BrC}$ is indicated by numbers in parentheses.

\begin{tabular}{llllll}
\hline \multicolumn{5}{c}{ AAOD at indicated wavelength } & AAE \\
\hline Wavelength & $350 \mathrm{~nm}$ & $450 \mathrm{~nm}$ & $550 \mathrm{~nm}$ & $650 \mathrm{~nm}$ & $\begin{array}{l}440- \\
870 \mathrm{~nm}\end{array}$ \\
& & & & & 0.9 \\
Without BrC & 0.0045 & 0.0039 & 0.0034 & 0.0029 & 0.9 \\
MOD BrC & 0.0062 & 0.0042 & 0.0035 & 0.003 & 1.0 \\
& $(+38 \%)$ & $(+8 \%)$ & $(+3 \%)$ & $(+3 \%)$ & \\
STR BrC & 0.007 & 0.0049 & 0.004 & 0.003 & 1.2 \\
& $(+56 \%)$ & $(+26 \%)$ & $(+18 \%)$ & $(+3 \%)$ & \\
\hline
\end{tabular}

the Southern Hemisphere, $\mathrm{BrC}$ in the Northern Hemisphere would have a large impact in densely populated areas, and its impact is likely to continue increasing in the future in the absence of emission controls for biofuels. At $550 \mathrm{~nm}$, the inclusion of $\mathrm{BrC}$ enhances the global and annual mean AAOD_NON by $+3 \%$ (the MOD case) to $+18 \%$ (the STR case) (Table 4), and is highly dependent on the absorption efficiency of BrC.

At the shorter wavelengths, $\mathrm{BrC}$ is a stronger and thus more important absorber than at $550 \mathrm{~nm}$. Without $\mathrm{BrC}$ 
(a)

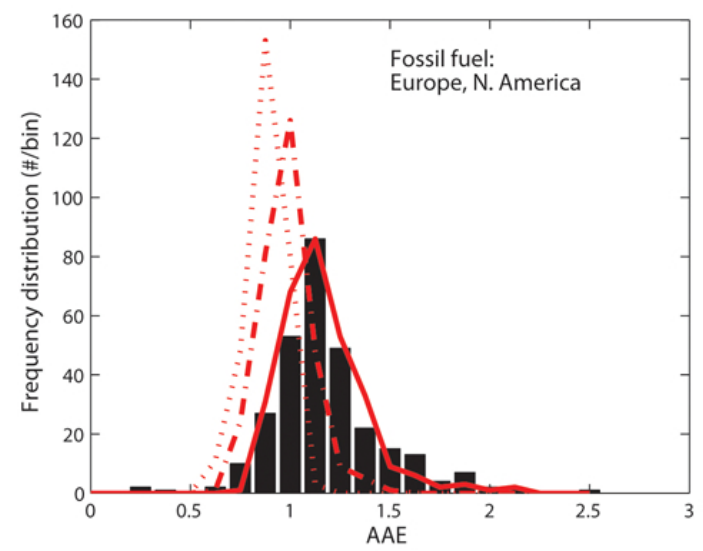

(c)

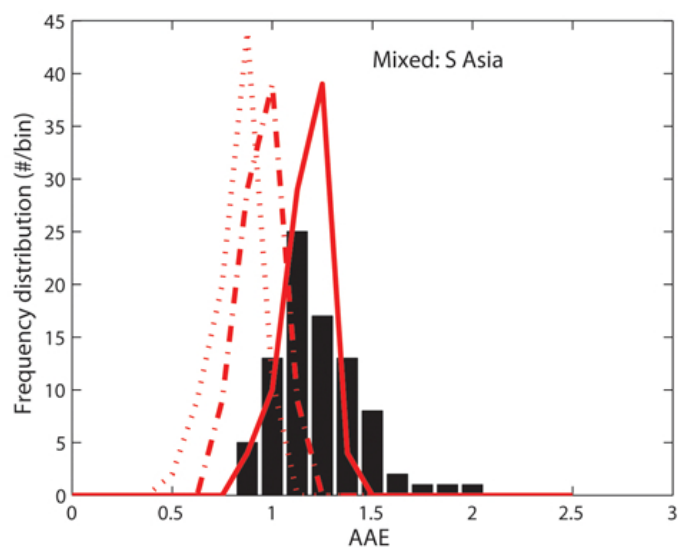

(b)

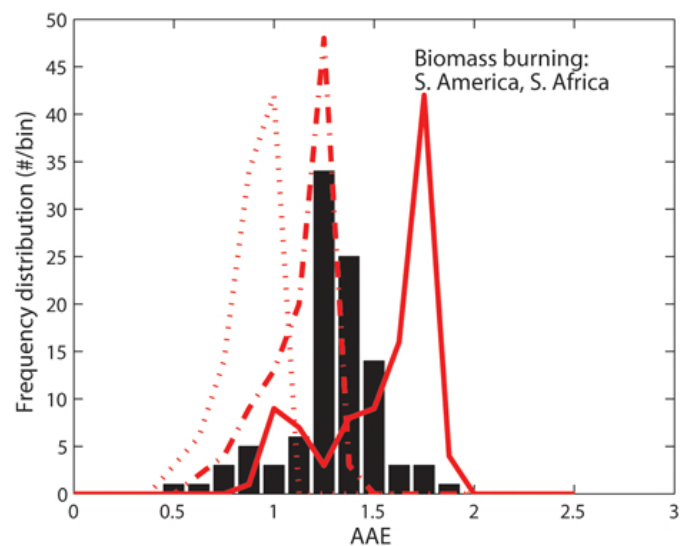

(d)

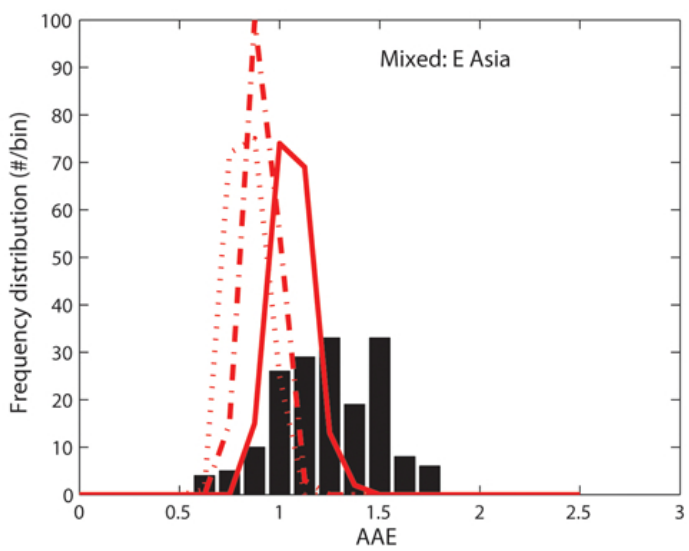

Fig. 6. Frequency distribution of the aerosol absorption Ångström exponent (AAE) at 440-870 nm, derived from the AERONET data (bar) and model simulations (in red). Dotted line, for the non-absorbing OC; dash-dot line, for the MOD BrC; solid line, for the STR BrC at 775 total AERONET sites. Distributions are over (a) fossil fuel-dominated Europe and North America, (b) open biomass burning-dominated South America and southern Africa, (c) mixed source region in South Asia, and (d) mixed source region in East Asia.

absorption, the calculated AAE_NON at $440-870 \mathrm{~nm}$ is mostly below 1.125 , with a mean of 0.9 over the AERONET sites (excluding those near-desert regions). This calculated absorption spectral dependence without $\mathrm{BrC}$ represents $\mathrm{BC}$ particles coated with non-absorbing sulfate or organic substances, as simulated by the model. This value is generally weaker than the AAE inferred from the AERONET data, which extends from 0.625 to 2 and has a mean value of 1.2. When $\mathrm{BrC}$ absorption is taken into account, the calculated AAOD is enhanced by $8 \%$ for the MOD case, by $26 \%$ for the STR case at $460 \mathrm{~nm}$, and by up to $56 \%$ for the AAOD_STR at $345 \mathrm{~nm}$ (Table 4). As a result, the augmented absorption at smaller wavelengths leads to larger AAE values for carbonaceous aerosols.

Figure 6 shows the frequency distribution of the simulated AAE with AERONET retrievals for different regions. Except over biomass burning-dominated South America and southern Africa, the model simulations of AAE_STR agree best with the observations, while the simulated AAE_NON values without absorbing $\mathrm{BrC}$ have a low bias. The width of the AAE frequency distribution implies the variability in aerosol size and composition. For the non-absorbing OC case, the frequency distribution indicates variations in the coating thickness on BC. Although no $\mathrm{BrC}$ is explicitly assumed to be associated with fossil fuel combustion, the AAE_STR distribution is in very good agreement with the AERONET data over Europe and North America when BrC from biofuel combustion and biomass burning is included. However, the simulated AAE_STR or AAE_MOD over East Asia and South Asia is still on the low end of the AERONET retrievals, even with the strongly absorbing $\mathrm{BrC}$. This could occur if some $\mathrm{BrC}$ in Asia has stronger absorption efficiency than the values reported by Kirchstetter et al. (2004) and Chen and Bond (2010). For instance, the tar balls (one of the common physical forms of $\mathrm{BrC}$ ) collected in the East Asian-Pacific outflow are suggested to be highly absorptive 


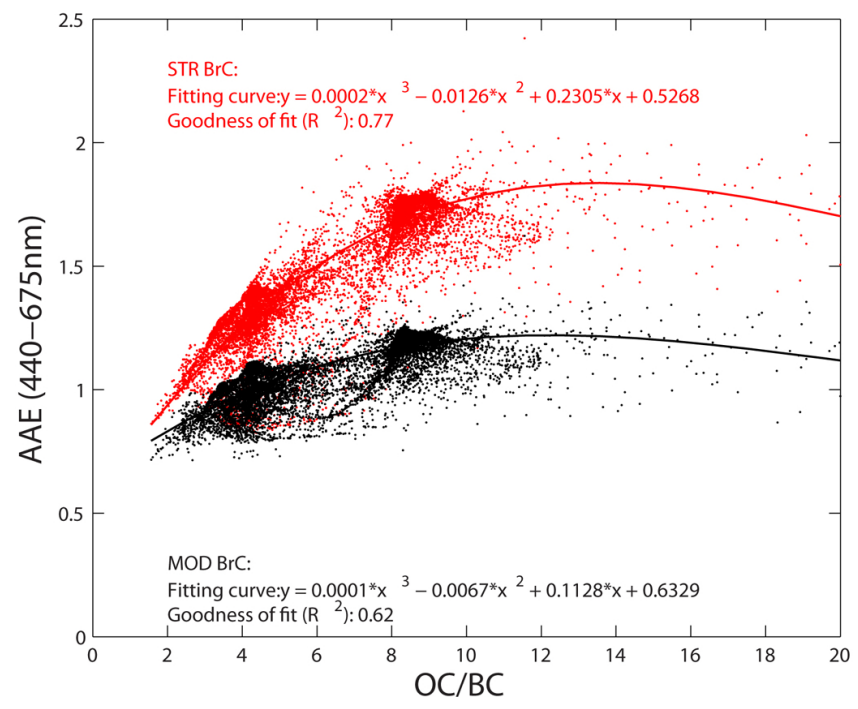

Fig. 7. The simulated wavelength dependence of AAE (440$675 \mathrm{~nm}$ ) as a function of the ratio of $\mathrm{OC}: \mathrm{BC}$ column burden, for the STR BrC and MOD BrC. The fitted curves are valid for ratios of $\mathrm{OC}$ : BC between 1.5 and 20.

(Alexander et al., 2008); this substance has a mean refractive index with an imaginary part of 0.27 at $550 \mathrm{~nm}$, about 10 times the value for the strongly absorbing $\mathrm{BrC}$ used in this study. Over the biomass burning regions, the AAE_STR is over-predicted, even though the absorption cross section used for strongly absorbing $\mathrm{BrC}$ is similar to that from the biomass burning aerosol samples (Kirchstetter et al., 2004). In those areas (Fig. 6b), the calculated AAE_MOD for moderately absorbing $\mathrm{BrC}$ agrees better with the observed $\mathrm{AAE}$ than does AAE_NON but is still low-biased, implying that $\mathrm{BrC}$ absorption from biomass burning sources is stronger than in the MOD case but less than the STR case.

Our calculations of the $\mathrm{BrC}$ spectral absorption for the STR or MOD cases are more consistent with several recent observationally based studies than are the results for the NON case. An analysis of AERONET data by Russell et al. (2010) suggested that the observed AAE values at 440-870 nm are 0.8-1.4 for urban sites (similar to Fig. 6a), and about 1.2-1.6 for biomass burning regions (similar to Fig. 6b). By applying an analytical partitioning method to the AERONET AOD and SSA values at $440 \mathrm{~nm}, 675 \mathrm{~nm}$, and $870 \mathrm{~nm}$, Bahadur et al. (2012) found that the $\mathrm{BrC}$ on average contributes $28 \%$ to the total aerosol absorption at $440 \mathrm{~nm}$, while our estimates of AAOD_STR and AAOD_MOD are about $26 \%$ and $8 \%$, respectively (Table 4 ).

Figure 7 shows the simulated AAE_STR for strongly absorbing $\mathrm{BrC}$ and $\mathrm{AAE} \_\mathrm{MOD}$ for moderately absorbing $\mathrm{BrC}$ between $440 \mathrm{~nm}$ and $675 \mathrm{~nm}$ as a function of $\mathrm{OC}$ : BC burden. The $\mathrm{OC}: \mathrm{BC}$ ratios in the global results are concentrated at values of $2-6$ and $8-10$, corresponding to fuel combustion and biomass burning source regions, respectively. The minimum value of AAE_STR in model calculations is about
0.825 at the $\mathrm{OC}: \mathrm{BC}$ ratio of 1.5 ; as the ratio $\mathrm{OC}: \mathrm{BC}$ increases, the calculated AAE_STR increases up to roughly 1.5-2, while the maximum AAE_MOD reaches to about 1.2. Because the absorption by $\mathrm{BrC}$ is close to zero near $675 \mathrm{~nm}$, the fitting curves for the strongly or moderately absorbing $\mathrm{BrC}$ simulations (solid lines in Fig. 7) could be useful for approximating the enhancement of AAOD due to $\mathrm{BrC} \mathrm{ab-}$ sorption at the smaller wavelengths for models that consider $\mathrm{BC}$ and non-absorbing $\mathrm{OC}$ only, on the basis of the simulated $\mathrm{OC}: \mathrm{BC}$ ratios and aerosol absorption at $675 \mathrm{~nm}$.

\subsection{Aerosol direct radiative forcing}

Direct radiative forcing by aerosols is estimated with the Monte Carlo Aerosol, Cloud and Radiation (MACR) model (Podgorny and Ramanathan, 2001; Kim and Ramanathan, 2008 ) for the predicted monthly mean aerosol optical properties. The MACR radiation model uses 25 bands to cover the solar spectrum from 0.25 to $5.0 \mathrm{~mm}$ with 50 layers (Vogelmann et al., 2001). The International Satellite Cloud Climatology Project satellite cloud cover and optical depth for low, middle, and high clouds were used in calculations of allsky radiative flux (Kim and Ramanathan, 2008). These values were interpolated to the T42 grid (approximately $2.8^{\circ}$ by $2.8^{\circ}$ ) as input fields to the MACR model, as well as the compiled monthly ozone, water vapor, and surface albedo data for the simulated year (Kim and Ramanathan, 2008).

Aerosol radiative forcing is estimated as the difference in the calculated radiative fluxes with all aerosols and with all aerosols except the aerosol type of interest. Figure 8 shows changes in the annual mean all-sky aerosol direct radiative forcing (DIR) due to the absorption of the strongly absorbing $\mathrm{BrC}$, along with the estimated DIR for organic aerosols (OAs) in the STR and NON cases. In Fig. 8a, the impact of the STR BrC on the aerosol TOA forcing is positive globally, suggesting an overall warming effect due to absorption of incoming solar radiation by $\mathrm{BrC}$. Because a similar effect (but to a smaller extent) was calculated for the MOD $\mathrm{BrC}$ relative to the NON case, we show only the STR BrC calculations in Figs. 8 and 9 for the regional analysis, though we show the global results for MOD BrC in Table 5. On a global mean basis, the inclusion of the MOD BrC or STR BrC might enhance total aerosol absorption by $7 \%$ or $19 \%$, respectively, depending on the assumed absorbing efficiencies (Table 5).

The magnitude of the $\mathrm{BrC}$ absorption in the atmosphere (about $0.1-0.25 \mathrm{~W} \mathrm{~m}^{-2}$ ) is comparable up to roughly one-quarter of the estimated atmospheric forcing of $\mathrm{BC}$ $\left(1.07 \mathrm{~W} \mathrm{~m}^{-2}\right)$. The global forcing of $\mathrm{BrC}$ relative to the nonabsorbing OC is roughly $0.04 \mathrm{~W} \mathrm{~m}^{-2}$ for the MOD BrC and $0.11 \mathrm{~W} \mathrm{~m}^{-2}$ for the STR BrC at the TOA, while the effect at the surface is negative, ranging from $-0.06 \mathrm{~W} \mathrm{~m}^{-2}$ (MOD) to $-0.14 \mathrm{~W} \mathrm{~m}^{-2}$ (STR). Regionally, the effects are more substantial. Figure 8a shows that the TOA forcing by the STR $\mathrm{BrC}$ is above $0.25 \mathrm{~W} \mathrm{~m}^{-2}$ over the major source regions, including subtropical southern Africa and South America, 

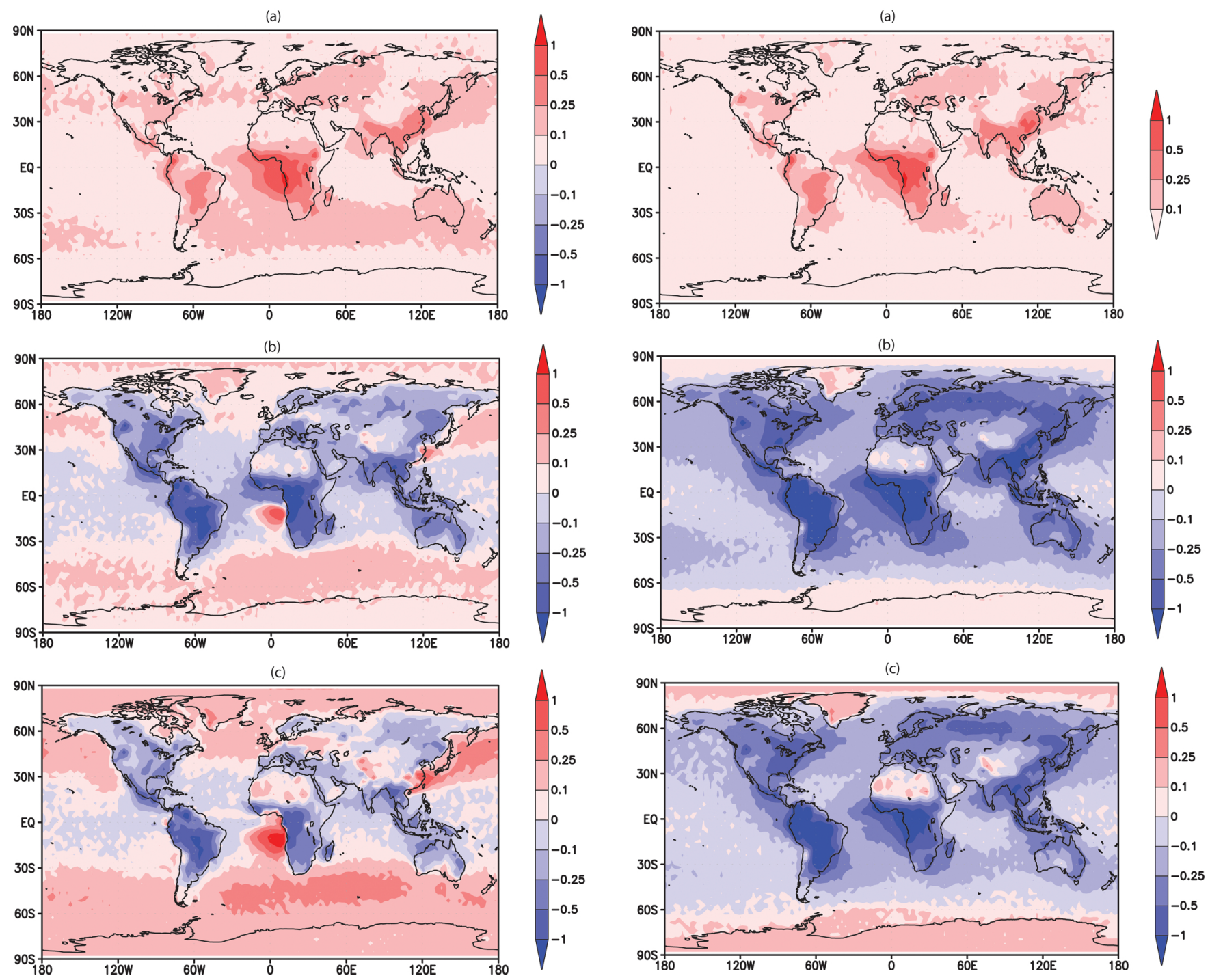

Fig. 8. The estimated annual mean all-sky direct radiative forcing $\left(\mathrm{W} \mathrm{m}^{-2}\right)$ at the top of the atmosphere by (a) the STR BrC relative to the non-absorbing $\mathrm{OC}$, (b) organic aerosols with the non-absorbing OC, and (c) organic aerosols with the STR BrC.

South Asia, and East Asia, which are dominated by biomass and biofuel burning.

When $\mathrm{OC}$ is not considered to be absorbing (no $\mathrm{BrC}$ ), OA consists of $100 \%$ non-absorbing OC and other scattering substances. Thus, the TOA forcing by OA is negative over most of the domain, expect for regions overlapping with marine low-level clouds and in high latitudes, as shown in Fig. 8b. Although OA does not absorb any solar radiation in the absence of absorbing $\mathrm{BrC}$, OAs could still enhance aerosol absorption by coating the $\mathrm{BC}$ particles. Especially over sea ice in high latitudes or above clouds (a bright surface with large surface albedo), small absorption $\left(\sim 0.5 \mathrm{~W} \mathrm{~m}^{-2}\right)$ due to the coating effect could cause a positive TOA forcing $\left(\sim 0.1 \mathrm{~W} \mathrm{~m}^{-2}\right)$. Accounting for the ab-

Fig. 9. As for Fig. 8, but for clear-sky forcing.

sorbing property of the STR $\mathrm{BrC}$ reduces the strong negative TOA forcing of OA, while increasing its weak positive forcing (Fig. 8c). The global mean OA direct radiative forcing is thus changed by the STR BrC from an overall negative effect $\left(-0.086 \mathrm{~W} \mathrm{~m}^{-2}\right)$ to a positive forcing $\left(+0.025 \mathrm{~W} \mathrm{~m}^{-2}\right)$.

The changes in the OA direct radiative forcing caused by $\mathrm{BrC}$ have significant implications on regional scales. Over east-central China and Europe, the radiative impact of total OA with the STR BrC might amplify (rather than offsetting, as originally estimated) the warming due to $\mathrm{BC}$ emitted from the same anthropogenic sources by adding an additional $0.25 \mathrm{~W} \mathrm{~m}^{-2}$ of warming. This implies that emission controls on fuel combustion should also include organic carbonaceous aerosols in addition to BC. Further, the STR $\mathrm{BrC}$ in biomass burning aerosols from the African savannas strongly intensifies the positive forcing of OAs off the western coast of central Africa, which is often overlaid with 
Table 5. Global and annual mean aerosol (fossil fuel, biofuel, and biomass burning) direct forcing for year 2000. Numbers in parentheses indicate the percent of the total aerosol forcing.

\begin{tabular}{lllllll}
\hline & \multicolumn{5}{c}{ Direct forcing $\left(\mathrm{W} \mathrm{m}^{-2}\right)$} \\
\cline { 2 - 7 } & $\begin{array}{l}\text { All aerosols } \\
\text { (this work) }\end{array}$ & $\begin{array}{l}\text { All aerosols } \\
\text { (AeroCom) }\end{array}$ & $\begin{array}{l}\mathrm{RC}^{2} 008^{2} \\
\text { (observation- } \\
\text { constrained) }\end{array}$ & $\begin{array}{l}\mathrm{BrC} \\
(\mathrm{MOD}-\mathrm{STR})\end{array}$ & $\mathrm{BC}$ & $\begin{array}{l}\text { Other } \\
\text { aerosols }\end{array}$ \\
\hline TOA & -0.17 & -0.22 & -0.4 & $0.04-0.11$ & 0.45 & -0.66 \\
Atmosphere & 1.47 & 0.82 & 3.0 & $0.1-0.25$ & 1.07 & 0.13 \\
Surface & -1.64 & -1.02 & -3.4 & -0.06 to -0.14 & -0.62 & -0.79 \\
& & & & $(7-11 \%)$ & $(41 \%)$ & $(48 \%)$ \\
\hline
\end{tabular}

${ }^{1}$ Schulz et al. (2006); ${ }^{2}$ RC2008: Ramanathan and Carmichael (2008).

subtropical stratocumulus cloud decks. The near-zero direct radiative forcing of $\mathrm{OA}$ at $30^{\circ} \mathrm{S}-5^{\circ} \mathrm{N}$ and $20^{\circ} \mathrm{W}-5^{\circ} \mathrm{E}$ in the NON case is changed by the STR BrC to a moderately positive forcing of $0.29 \mathrm{~W} \mathrm{~m}^{-2}$, which could significantly alter regional cloud and precipitation formation related to the African monsoon (e.g., Huang et al., 2009; Sakaeda et al., 2011). Over mid-latitude oceans and higher altitudes, the weakly positive TOA forcing by OA in the NON case is nearly doubled by the transported $\mathrm{BrC}$ with strong absorption. Although the absolute aerosol forcing is small (0.1$0.25 \mathrm{~W} \mathrm{~m}^{-2}$ ) in the polar regions, the high-altitude climate is highly sensitive to aerosol perturbations (Shindell and Faluvegi, 2009).

Figure 9 shows that under clear sky, the STR BrC direct radiative forcing without cloud masks is larger over the land, where aerosols are mostly below clouds; on the other hand, the radiative impact of the STR BrC transported over the ocean is less in clear sky, in the absence of amplified absorption from the reflection of clouds underneath. As a result, the clear-sky TOA forcing of OA is predominately more negative than under cloudy sky, either for the non-absorbing OC or the STR BrC. The estimated global effect of the STR BrC in the clear sky $\left(+0.09 \mathrm{~W} \mathrm{~m}^{-2}\right)$ is slightly less than in all sky conditions $\left(+0.11 \mathrm{~W} \mathrm{~m}^{-2}\right)$.

The TOA forcing by all anthropogenic aerosols is estimated at about $-0.17 \mathrm{~W} \mathrm{~m}^{-2}$ in the present study (Table 5). This value is similar to the AeroCom model estimate of $-0.21 \pm 0.20 \mathrm{~W} \mathrm{~m}^{-2}$ with similar emissions ${ }^{1}$ (Schulz et al., 2006). The estimated total atmospheric absorption $\left(+1.47 \mathrm{~W} \mathrm{~m}^{-2}\right)$ and surface dimming $\left(-1.64 \mathrm{~W} \mathrm{~m}^{-2}\right)$ by aerosols are more significant - roughly $80 \%$ and $38 \%$ larger than the AeroCom means. Other anthropogenic aerosols, including sulfate and non-absorbing organic matter, could also increase aerosol absorption by coating $\mathrm{BC}$ particles. The esti-

\footnotetext{
${ }^{1}$ The AeroCom forcing quoted is the sum of the AeroCom anthropogenic aerosol forcing, $-0.22 \pm 0.16 \mathrm{~W} \mathrm{~m}^{-2}$, and biomass burning aerosol forcing, $0.01 \pm 0.04 \mathrm{~W} \mathrm{~m}^{-2}$ (Schulz et al., 2006), because we consider open biomass burning aerosols as anthropogenic sources.
}

mated enhancement due to the non-absorbing aerosol coating effect adds another $9 \%$ to the total absorption in the STR case. Compared with the observationally constrained estimate $\left(3.0 \mathrm{~W} \mathrm{~m}^{-2}\right)$ of Ramanathan and Carmichael (2008), the global calculations that include strongly absorbing $\mathrm{BrC}$ (the STR BrC case) still underestimate the atmospheric absorption $\left(1.47 \mathrm{~W} \mathrm{~m}^{-2}\right)$. One of the reasons might be underpredicted aerosol loadings; in particular, we note that the AOD comparison with MODIS satellite data in Fig. 3 indicates underestimation in biomass burning regions.

Seasonal variations in the predicted burden and atmospheric forcing of the STR BrC are shown in Fig. 10 for three locations with high $\mathrm{BrC}$ content. Like the $\mathrm{BrC}$ burdens inferred from the AERONET data (Arola et al., 2011), the model predictions peak in July-August-September at the two open biomass burning locations in South America (Alta Floresta, Brazil) and southern Africa (Mongu, Zambia), and the predicted burdens are also in similar ranges (about 5$15 \mathrm{mg} \mathrm{m}^{-2}$ ). However, the estimated $\mathrm{BrC}$ is significantly low-biased in Kanpur, India, compared to the observationally based estimate. This is probably because BC emissions in South Asia might have been increasing during the past two decades (Bond et al., 2007); these emission increases might not be included in the global emission inventories for year 2000 used here. As for the atmospheric burden, the predicted forcing for the STR BrC depicts a strong seasonal cycle, peaking during the dry burning seasons in both hemispheres (Fig. 10). The maximum monthly forcing by the STR BrC is about $5 \mathrm{~W} \mathrm{~m}^{-2}$ at the southern African site in September.

\section{Conclusions}

Increasing evidence points to the existence of $\mathrm{BrC}$ in the atmosphere. The strong wavelength dependence from the ultraviolet to the visible in the observed carbonaceous aerosol absorption (AAE > 2) cannot be explained by mixing of BC with other scattering aerosols. Several observationally based studies have inferred the absorption cross section of $\mathrm{BrC}$ on 
(a)

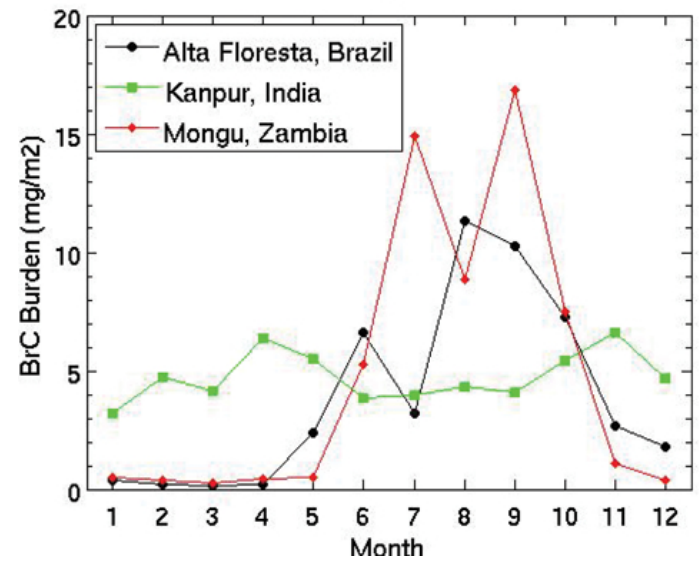

(b)

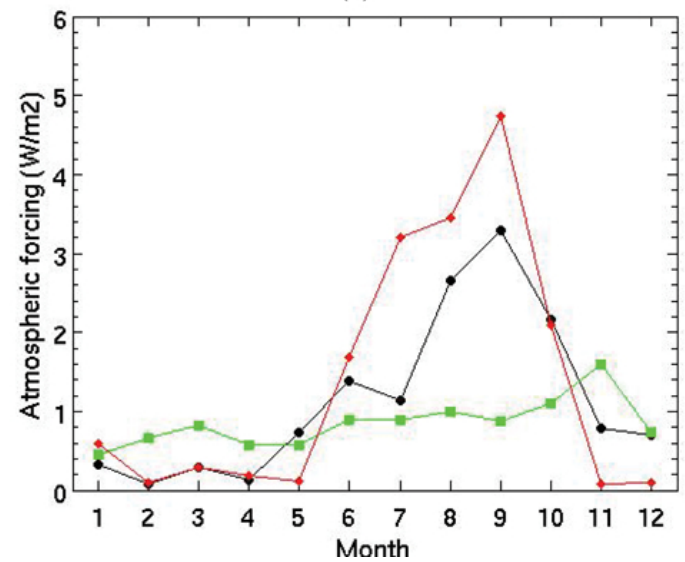

Fig. 10. Seasonal variations in the model predictions of (a) $\mathrm{BrC}$ burden $\left(\mathrm{mg} \mathrm{m}^{-2}\right)$ and (b) atmospheric absorption (W m $\left.{ }^{-2}\right)$ due to the $\mathrm{STR}$ BrC at Alta Floresta, Brazil (56.1 $\left.{ }^{\circ} \mathrm{W}, 9.87^{\circ} \mathrm{S}\right)$, Kanpur, India $\left(80.23^{\circ} \mathrm{E}, 26.51^{\circ} \mathrm{N}\right)$, and Mongu, Zambia $\left(23.15^{\circ} \mathrm{E}, 15.25^{\circ} \mathrm{S}\right)$.

the basis of multi-wavelength absorption measurements and have demonstrated significant absorption attributed to $\mathrm{BrC}$ in the ultraviolet and visible ranges in laboratory studies or over observational sites (e.g., Kirchstetter et al., 2004; Chen and Bond, 2010; Bahadur et al., 2012; Kirchstetter and Thatcher, 2012). By integrating ground-based aerosol data with field and satellite observations, Chung et al. (2012) found that the global OA radiative forcing is close to zero when the contribution of $\mathrm{BrC}$ is implicitly included in the aerosol absorption spectrum. However, whether the $\mathrm{BrC}$ absorption could play a significant role in global and regional direct radiative forcing of carbonaceous aerosols remains uncertain.

We examined the enhancement in the absorption of solar radiation due to $\mathrm{BrC}$ with emissions compiled for year 2000 and generated the first estimate of global direct radiative forcing by $\mathrm{BrC}$ relative to non-absorbing OC. Given the large variability in the observed absorption cross section (Chen and Bond, 2010), we derived two sets of refractive index data to represent the moderately and strongly absorbing $\mathrm{BrC}$ types, MOD BrC and STR BrC.

The main findings of this study are as follows:

1. The inclusion of both MOD BrC and STR BrC absorption properties leads to stronger wavelength dependence in the calculated aerosol absorption. The simulated aerosol AAE increases from 0.9 for the nonabsorbing OC only, to 1.0 with moderately absorbing $\mathrm{BrC}$, and to 1.2 with strongly absorbing $\mathrm{BrC}$; on average, the last value agrees best with AERONET spectral retrievals.

2. The enhancement in the global mean AAOD due to STR BrC is up to $18 \%$ at $550 \mathrm{~nm}$, and it increases drastically to $56 \%$ at $350 \mathrm{~nm}$. This enhanced absorption of solar radiation by aerosols in the ultraviolet and near visible could imply a large impact on photolysis reaction rates and ozone photochemistry.
3. Model simulations suggest that the inclusion of $\mathrm{BrC}$ absorption results in a forcing of $+0.11 \mathrm{~W} \mathrm{~m}^{-2}$ for the STR BrC and of $+0.04 \mathrm{~W} \mathrm{~m}^{-2}$ for the MOD BrC at the TOA. The estimated effect of the STR BrC changes the global radiative forcing of organic carbonaceous aerosols from cooling $\left(-0.08 \mathrm{~W} \mathrm{~m}^{-2}\right)$ to warming $\left(+0.025 \mathrm{~W} \mathrm{~m}^{-2}\right)$, with much larger impact on regional climate. Therefore, failure to include the atmospheric heating $\left(+0.1\right.$ to $\left.+0.25 \mathrm{~W} \mathrm{~m}^{-2}\right)$ and surface dimming ( -0.06 to $-0.14 \mathrm{~W} \mathrm{~m}^{-2}$ ) by MOD BrC to STR BrC, respectively, in climate simulations could introduce a significant source of uncertainty.

4. While $\mathrm{BC}$ is still the main absorber of solar radiation - contributing $72 \%$ of the global atmospheric absorption - the contribution of the STR BrC to aerosol forcing is $>20-50 \%$ over regions dominated by seasonal biomass burnings and biofuel combustion, accounting for more than a quarter of the estimated radiative effects of $\mathrm{BC}$ on a global basis.

5. The atmospheric burden of $\mathrm{BrC}$ is estimated to be $0.65 \mathrm{mg} \mathrm{m}^{-2}$, which is more than three times the burden of BC. Since most of the $\mathrm{BrC}$ is associated with biomass burning aerosols, $\mathrm{BrC}$ aerosols are more likely to be elevated high above clouds and transported long distances than are the surface-emitted aerosols, leading to more widespread and efficient warming.

With respect to $\mathrm{BrC}$, large uncertainties still remain regarding to its sources, formation, chemical composition, absorption properties, and scavenging process (thus lifetime). In the present study, we simplified $\mathrm{BrC}$ production by assigning $92 \%$ of biomass and biofuel burning $\mathrm{OC}$ mass as $\mathrm{BrC}$, on the basis of a study of solid fuels (Chen and Bond, 2010). This fraction might be close to a possible maximum of $\mathrm{BrC}$ in total carbon. If that assumption holds, the contribution of $\mathrm{BrC}$ to 
atmospheric absorption would not exceed the predicted $19 \%$ on a global and annual basis. The uncertainty in the assumed absorption cross section for $\mathrm{BrC}$ causes the predicted global and annual mean contribution of $\mathrm{BrC}$ to aerosol absorption to range from $7 \%$ (moderately absorbing) to $19 \%$ (strongly absorbing). However, the absolute radiative impact of $\mathrm{BrC}$ could still be larger than the present estimates. For example, underestimation could arise from under-predicted biomass burning or biofuel aerosol emissions, along with uncertainty in representing aerosol size and mixing state.

Therefore, the first global estimates of $\mathrm{BrC}$ radiative forcing in this study might demonstrate that $\mathrm{BrC}$ is an important atmospheric absorber, globally and regionally. These estimates should also motivate further efforts to quantify $\mathrm{BrC}$ in the atmosphere and to reduce the gap in aerosol absorption values between observationally based and global modeling studies.

\section{Appendix A}

The IMPACT model uses a flux-form semi-Lagrangian advection scheme (Lin and Rood, 1996). Aerosol dry and wet deposition are based on a resistance-in-series parameterization (Zhang et al., 2001) and the Harvard wet scavenging model (Liu et al., 2001), respectively. In convective updrafts, the fraction of tracer scavenged is calculated by the conversion rate of cloud condensate to precipitation $\left(0.005 \mathrm{~s}^{-1}\right)$ and the scavenging efficiency (fraction of tracer present in the cloud condensate). The scavenging efficiencies of sulfate, nitrate, ammonium, and carbonaceous aerosol are 1.0, 1.0, 1.0, and 0.4 , respectively. The rainout rate depends on the tracer scavenging efficiency, the precipitating fraction of the grid box, and the conversion rate of cloud condensate to precipitation. Washout rate by large-scale precipitation is computed by a constant scavenging efficiency, $0.1 \mathrm{~mm}^{-1}$, multiplied by the precipitation rate (in $\mathrm{mm} \mathrm{h}^{-1}$ ) (Balkanski et al., 1993). Resuspension is calculated in any grid box with net evaporation of precipitation. Cumulus transport was derived from the relaxed Arakawa-Schubert scheme, as described in Penner et al. (1998).

Acknowledgements. Support to Y. Feng and V. R. Kotamarthi for this research was provided by Argonne National Laboratory under US Department of Energy contract DE-AC02-06CH11357. V. Ramanathan's contribution to this study was supported by the National Science Foundation (Grant AGS1016496). All of the numerical simulations were performed by using the National Energy Research Scientific Computing Center's CrayXE6 Hopper.

Edited by: H. Su

\section{References}

Alexander, D. T. L., Crozier, P. A., and Anderson, J. R.: Brown carbon spheres in East Asian outflow and their optical properties, Science, 321, 833-836, doi:10.1126/science.1155296, 2008.
Anderson, B. E., Grant, W. B., Gregory, G. L., Browell, E. V., Collins Jr., J. E., Sachse, D. W., Bagwell, D. R., Hudgins, C. H., Blake, D. R., and Blake, N. J.: Aerosols from biomass burning over the tropical South Atlantic region: distributions and impacts, J. Geophys. Res., 101, 24117-24138, doi:10.1029/96JD00717, 1996.

Andreae, M. O. and Gelencsér, A.: Black carbon or brown carbon? The nature of light-absorbing carbonaceous aerosols, Atmos. Chem. Phys., 6, 3131-3148, doi:10.5194/acp-6-31312006, 2006.

Andrews, T., Forster, P. M., Boucher, O., Bellouin, N., and Jones, A.: Precipitation, radiative forcing and global temperature change, Geophys. Res. Lett., 37, L14701, doi:10.1029/2010GL043991, 2010.

Arola, A., Schuster, G., Myhre, G., Kazadzis, S., Dey, S., and Tripathi, S. N.: Inferring absorbing organic carbon content from AERONET data, Atmos. Chem. Phys., 11, 215-225, doi:10.5194/acp-11-215-2011, 2011.

Bahadur, R., Praveen, P. S., Xu, Y., and Ramanathan, V.: Solar absorption by elemental and brown carbon determined from spectral observations, P. Natl. Acad. Sci. USA, 109, 17366-17371, doi:10.1073/pnas.1205910109, 2012.

Balkanski, Y. J., Jacob, D. J., Gardner, G. M., Graustein, W. M., and Turekian, K. K.: Transport and residence times of continental aerosols inferred from a global 3-dimensional simulation of ${ }^{210}$ Pb, J. Geophys. Res., 98, 20573-20586, 1993.

Bohren C. F. and Huffman D: Absorption and scattering of light by small particles. Wiley, New York, 530 pp., 1983.

Bond, T. C.: Spectral dependence of visible light absorption by carbonaceous particles emitted from coal combustion, Geophys. Res. Lett., 28, 4075-4078, 2001.

Bond, T. C. and Bergstrom, R. W.: Light absorption by carbonaceous particles: an investigative review, Aerosol Sci. Tech., 40, 27-67, 2006.

Bond, T. C., Habib, G., and Bergstrom, R. W.: Limitations in the enhancement of visible light absorption due to mixing state, J. Geophys. Res., 111, D20211, doi:10.1029/2006JD007315, 2006.

Bond, T. C., Bhardwaj, E., Dong, R., Jogani, R., Jung, S., Roden, C., Streets, D. G., and Trautmann, N. M.: Historical emissions of black and organic carbon aerosol from energy-related combustion, 1850-2000, Global Biogeochem. Cy., 21, GB2018, doi:10.1029/2006GB002840, 2007.

Chen, Y. and Bond, T. C.: Light absorption by organic carbon from wood combustion, Atmos. Chem. Phys., 10, 1773-1787, doi:10.5194/acp-10-1773-2010, 2010.

Chuang, C. C., Penner, J. E., Taylor, K. E., Grossman, A. S., and Walton, J. J.: An assessment of the radiative effects of anthropogenic sulfate, J. Geophys. Res., 102, 3761-3778, 1997.

Chung, C. E., Ramanathan, V., and Decremer, D.: Observationally constrained estimates of carbonaceous aerosol radiative forcing, P. Natl. Acad. Sci. USA, 109, 11624-11629, 2012

d'Almeida, G. A., Koepke, P., and Shettle, E. P.: Atmospheric Aerosols: Global Climatology and Radiative Characteristics, A. Deepak Pub., Hampton, VA, 1991.

Dentener, F., Kinne, S., Bond, T., Boucher, O., Cofala, J., Generoso, S., Ginoux, P., Gong, S., Hoelzemann, J. J., Ito, A., Marelli, L., Penner, J. E., Putaud, J.-P., Textor, C., Schulz, M., van der Werf, G. R., and Wilson, J.: Emissions of primary aerosol and precursor gases in the years 2000 and 1750 prescribed data-sets for 
AeroCom, Atmos. Chem. Phys., 6, 4321-4344, doi:10.5194/acp6-4321-2006, 2006.

Dubovik, O., Sinyuk, A., Lapyonok, T., Holben, B. N., Mishchenko, M., Yang, P., Eck, T. F., Volten, H., Muñoz, O., Veihelmann, B., van der Zande, W. J., Leon, J.-F., Sorokin, M., and Slutsker, I.: Application of spheroid models to account for aerosol particle nonsphericity in remote sensing of desert dust, J. Geophys. Res., 111, D11208, doi:10.1029/2005JD006619, 2006.

Feng, Y. and Penner, J. E.: Global modeling of nitrate and ammonium: Interaction of aerosols and tropospheric chemistry, J. Geophys. Res., 112, D01304, doi:10.1029/2005JD006404, 2007.

Feng, Y. and Ramanathan, V.: Investigation of aerosol-cloud interactions using a chemical transport model constrained by satellite observations, Tellus, 62B, 69-86, 2010.

Forster, P., Ramaswamy, V., Artaxo, P., Berntsen, T., Betts, R., Fahey, D. W., Haywood, J., Lean, J., Lowe, D. C., Myhre, G., Nganga, J., Prinn, R., Raga, G., Schulz, M., and Van Dorland, R.: Chapter: Changes in atmospheric constituents and in radiative forcing, in: Climate Change 2007: The Physical Science Basis. Contribution of Working Group I to the Fourth Assessment Report of the Intergovernmental Panel on Climate Change, edited by: Solomon, S., Qin, D., Manning, M., Chen, Z., Marquis, M., Averyt, K. B., Tignor, M., and Miller, H. L., Cambridge Univ. Press, New York, 2007.

Ganguly, D., Rasch, P. J., Wang, H., and Yoon, J.: Climate response of the South Asian monsoon system to anthropogenic aerosols, J. Geophys. Res., 117, D13209, doi:10.1029/2012JD017508, 2012.

Ginoux, P., Chin, M., Tegen, I., Prospero, J. M., Holben, B., Dubovik, O., and Lin, S.-J.: Sources and distributions of dust aerosols simulated with the GOCART model, J. Geophys. Res., 106, 20255-20274, 2001.

Hoffer, A., Gelencsér, A., Guyon, P., Kiss, G., Schmid, O., Frank, G. P., Artaxo, P., and Andreae, M. O.: Optical properties of humic-like substances (HULIS) in biomass-burning aerosols, Atmos. Chem. Phys., 6, 3563-3570, doi:10.5194/acp-6-3563-2006, 2006.

Holben, B. N., Eck, T. F., Slutsker, I., Tanre, D., Buis, J. P., Setzer, A., Vermote, E., Reagan, J. A., Kaufman, Y. J., Nakjima, T., Lavenu, F., Jankowiak, I., and Smirnov, A.: AERONE - A federated instrument network and data archive for aerosol characterization, Remote Sens. Environ., 66, 1-16, 1998.

Huang, J., Zhang, C., and Prospero, J. M.: Large-scale effect of aerosols on precipitation in the West African Monsoon region, Q. J. Roy. Meteorol. Soc., doi:10.1002/qj.391, 2009.

Jacobson, M. Z.: Global direct radiative forcing due to multicomponent anthropogenic and natural aerosols, J. Geophys. Res., 106, 1551-1568, 2001.

Jacobson, M. Z.: Short-term effects of controlling fossil-fuel soot, biofuel soot and gases, and methane on climate, Arctic ice, and air pollution health, J. Geophys. Res., 115, D14209, doi:10.1029/2009JD013795, 2010.

Kettle, A. J. and Andreae, M. O.: Flux of dimethylsulfide from the oceans: a comparison of updated data seas and flux models, J. Geophys. Res.-Atmos., 105, 26793-26808, 2000.

Kim, D. and Ramanathan, V.: Solar radiation budget and radiative forcing due to aerosols and clouds, J. Geophys. Res., 113, D02203, doi:10.1029/2007JD008434, 2008.

Kinne, S., Schulz, M., Textor, C., Guibert, S., Balkanski, Y., Bauer, S. E., Berntsen, T., Berglen, T. F., Boucher, O., Chin, M., Collins,
W., Dentener, F., Diehl, T., Easter, R., Feichter, J., Fillmore, D., Ghan, S., Ginoux, P., Gong, S., Grini, A., Hendricks, J., Herzog, M., Horowitz, L., Isaksen, I., Iversen, T., Kirkevåg, A., Kloster, S., Koch, D., Kristjansson, J. E., Krol, M., Lauer, A., Lamarque, J. F., Lesins, G., Liu, X., Lohmann, U., Montanaro, V., Myhre, G., Penner, J., Pitari, G., Reddy, S., Seland, O., Stier, P., Takemura, T., and Tie, X.: An AeroCom initial assessment - optical properties in aerosol component modules of global models, Atmos. Chem. Phys., 6, 1815-1834, doi:10.5194/acp-6-1815-2006, 2006.

Kirchstetter, T. W. and Thatcher, T. L.: Contribution of organic carbon to wood smoke particulate matter absorption of solar radiation, Atmos. Chem. Phys., 12, 6067-6072, doi:10.5194/acp-126067-2012, 2012.

Kirchstetter, T. W., Novakov, T., and Hobbs, P. V.: Evidence that the spectral dependence of light absorption by aerosols is affected by organic carbon, J. Geophys. Res., 109, D21208, doi:10.1029/2004JD004999, 2004.

Koch, D., Schulz, M., Kinne, S., McNaughton, C., Spackman, J. R., Balkanski, Y., Bauer, S., Berntsen, T., Bond, T. C., Boucher, O., Chin, M., Clarke, A., De Luca, N., Dentener, F., Diehl, T., Dubovik, O., Easter, R., Fahey, D. W., Feichter, J., Fillmore, D., Freitag, S., Ghan, S., Ginoux, P., Gong, S., Horowitz, L., Iversen, T., Kirkevåg, A., Klimont, Z., Kondo, Y., Krol, M., Liu, X., Miller, R., Montanaro, V., Moteki, N., Myhre, G., Penner, J. E., Perlwitz, J., Pitari, G., Reddy, S., Sahu, L., Sakamoto, H., Schuster, G., Schwarz, J. P., Seland, Ø., Stier, P., Takegawa, N., Takemura, T., Textor, C., van Aardenne, J. A., and Zhao, Y.: Evaluation of black carbon estimations in global aerosol models, Atmos. Chem. Phys., 9, 9001-9026, doi:10.5194/acp-9-9001-2009, 2009.

Limbeck, A., Kulmala, M., and Puxbaum, H.: Secondary organic aerosol formation in the atmosphere via heterogeneous reaction of gaseous isoprene on acidic particles, Geophys. Res. Lett., 30, 1996, doi:10.1029/2003GL017738, 2003.

Lin, S.-J. and Rood, R. B.: Multidimensional flux-form semiLagrangian transport schemes, Mon. Weather Rev., 124, 20462070, 1996.

Liu, H., Jacob, D. J., Bey, I., and Yantosca, R. M.: Constraints from ${ }^{210} \mathrm{~Pb}$ and ${ }^{7} \mathrm{Be}$ on wet deposition and transport in a global threedimensional chemical tracer model driven by assimilated meteorological fields, J. Geophys. Res., 106, 12109-12128, 2001.

Liu, X. and Penner, J. E.: Effect of Mt. Pinatubo H2SO4/H2O aerosol on ice nucleation in the upper troposphere using a global chemistry and transport model (IMPACT), J. Geophys. Res., 107, 4141, doi:10.1029/2001JD000455, 2002.

Liu, X., Penner, J. E., and Herzog, M.: Global simulation of aerosol dynamics: Model description, evaluation, and interactions between sulfate and nonsulfate aerosols, J. Geophys. Res., 110, D18206, doi:10.1029/2004JD005674, 2005.

Liu, X., Penner, J. E., Das, B., Bergmann, D., Rodriguez, J. M., Strahan, S., Wang, M., and Feng, Y.: Uncertainties in global aerosol simulations: Assessment using three meteorological datasets, J. Geophys. Res., 112, D11212, doi:10.1029/2006JD008216, 2007.

Menon, S., Koch, D., Beig, G., Sahu, S., Fasullo, J., and Orlikowski, D.: Black carbon aerosols and the third polar ice cap, Atmos. Chem. Phys., 10, 4559-4571, doi:10.5194/acp-10-4559-2010, 2010 . 
Ming, Y., Ramaswamy, V., and Persad, G.: Two opposing effects of absorbing aerosols on global-mean precipitation, Geophys. Res. Lett., 37, L13701, doi:10.1029/2010GL042895, 2010.

Monahan, E. C., Spiel, D. E. and Davidson, K. L.: A Model of Marine Aerosol Generation via Whitecaps and Wave Disruption, D. Reidel, Norwell, MA, 1986.

Mukai, H. and Ambe, Y.: Characterization of a humic acid-like brown substance in airborne particulatematter and tentative identification of its origin, Atmos. Environ., 20, 813-819, 1986.

Olivier, J. G. J. and Berdowski, J. J. M.: Global emissions sources and sinks, in: The Climate System, edited by: Berdowski, J., Guicherit, R., and Heij, B. J., A.A. Balkema Publishers/Swets \& Zeitlinger Publishers, Lisse, The Netherlands, 33-78, 2001.

Olivier, J. G. J., Berdowski, J. J. M., Peters, J., Bakker, J., Visschedijk, A., and Bloos, J.: Applications of EDGAR. Including a description of EDGAR 3.0: reference database with trend data for 1970-1995, RIVM, Bilthoven, RIVM report no. 773301 001/NOP report no. 410200 051, 2001.

Park, R. J., Kim, M. J., Jeong, J. I., Youn, D., and Kim, S.: A contribution of brown carbon aerosol to the aerosol light absorption and its radiative forcing in East Asia, Atmos. Environ., 44, 14141421,2010

Penner, J. E., Chuang, C., and Grant, K.: Climate forcing by carbonaceous and sulfate aerosols, Clim. Dynam., 14839-14851, 1998.

Penner, J. E., Andrae, M., Annegarn, H., Barrie, L., Feichter, J., Hegg, D., Jayaraman, A., Leaitch, R., Murphy, D., Nganga, J., Pitari, G., Ackerman, A., Adams, P., Austin, P., Boers, R., Boucher, O., Chin, M., Chuang, C., Collins, B., Cooke, W., DeMott, P., Feng, Y., Fisher, H., Fung, I., Ghan, S., Ginoux, P., Gong, S.-L., Guenther, A., Herzog, M., Higurashi, A., Kaufman, Y., Kettle, A., Kiehl, J., Koch, D., Lammel, G., Land, C., Lohmann, U., Madronich, S., Mancini, E., Mishchenko, M., Nakajima, T., Quinn, P., Rasch, P., Roberts, D. L., Savoie, D., Schwartz, S., Seinfield, J., Soden, B., Tanre, D., Taylor, K., Tegen, I., Tie,X., Vali., G., Van Dingenen, R., Weele, M. V., and Zhang, Y.: Aerosols, their direct and indirect effects, a chapter in Climate Change 2001: Contributions of Working Group I to the Third Assessment Report of the Intergovernmental Panel on Climate Change, 289-348, Cambridge University Press, New York, USA, 2001

Penner, J. E., Zhang, S. Y., and Chuang, C. C.: Soot and smoke aerosol may not warm climate, J. Geophys. Res., 108, 4657, doi:10.1029/2003JD003409, 2003.

Podgorny, I. A. and Ramanathan, V.: A modeling study of the direct effect of aerosols over the tropical Indian Ocean, J. Geophys. Res., 106, 24097-24105, 2001

Radke, L. F., Hegg, D. A., Lyons, J. H., Brock, C. A., Hobbs, P. V., Weiss, R., and Rasmussen, R.: Airborne Measurements on Smoke from Biomass Burning, A. Deepak, Hampton, VA, 1988.

Ramanathan, V. and Carmichael, G.: Global and regional climate changes due to black carbon, Nat. Geosci., 1, 221-227, 2008.

Rotman, D. A., Atherton, C. S., Bergmann, D. J., Cameron-Smith, P. J., Chuang, C. C., Connell, P. S., Dignon, J. E., Franz, A., Grant, K. E., Kinnison, D. E., Molenkamp, C. R., Proctor, D. D., and Tannahill, J. R.: IMPACT, the LLNL 3-D global atmospheric chemical transport model for the combined troposphere and stratosphere: Model description and analysis of ozone and other trace gases, J. Geophys. Res., 109, D04303,
doi:10.1029/2002JD003155, 2004.

Russell, P. B., Bergstrom, R. W., Shinozuka, Y., Clarke, A. D., DeCarlo, P. F., Jimenez, J. L., Livingston, J. M., Redemann, J., Dubovik, O., and Strawa, A.: Absorption Angstrom Exponent in AERONET and related data as an indicator of aerosol composition, Atmos. Chem. Phys., 10, 1155-1169, doi:10.5194/acp-101155-2010, 2010.

Sakaeda, N., Wood, R., and Rasch, P. J.: Direct and semidirect aerosol effects of southern African biomass burning aerosol, J. Geophys. Res.-Atmos., 116, D12205, doi:10.1029/2010JD015540, 2011.

Sato, M., Hansen, J., Koch, D., Lacis, A., Ruedy, R., Dubovik, O., Holben, B., Chin, M., and Novakov, T.: Global atmospheric black carbon inferred from AERONET, P. Natl. Acad. Sci. USA, 100, 6319-6324, doi:10.1073/pnas.0731897100, 2003.

Schulz, M., Textor, C., Kinne, S., Balkanski, Y., Bauer, S., Berntsen, T., Berglen, T., Boucher, O., Dentener, F., Guibert, S., Isaksen, I. S. A., Iversen, T., Koch, D., Kirkevåg, A., Liu, X., Montanaro, V., Myhre, G., Penner, J. E., Pitari, G., Reddy, S., Seland, $\varnothing$. ., Stier, P., and Takemura, T.: Radiative forcing by aerosols as derived from the AeroCom present-day and pre-industrial simulations, Atmos. Chem. Phys., 6, 5225-5246, doi:10.5194/acp-65225-2006, 2006

Shindell, D. and Faluvegi, G.: Climate response to regional radiative forcing during the twentieth century, Nat. Geosci., 2, 294-300, doi:10.1038/NGEO473, 2009.

Shindell, D., Kuylenstierna, J. C. I., Vignati, E., van Dingenen, R., Amann, M., Klimont, Z., Anenberg, S. C., Muller, N., JanssensMaenhout, G., Raes, F., Schwartz, J., Faluvegi, G., Pozzoli, L., Kupiainen, K., Höglund-Isaksson, L., Emberson, L., Streets, D., Ramanathan, V., Hicks, K., Kim Oanh, N. T., Milly, G., Williams, M., Demkine, V., and Fowler, D.: Simultaneously mitigating near-term climate change and improving human health and food security, Science, 335, 183-189, 2012.

Torres, O., Tanskanen, A., Veihelmann, B., Ahn, C., Braak, R., Bhartia, P. K., Veefkind, P., and Levelt, P.: Aerosols and surface UV products from Ozone Monitoring Instrument observations: an overview, J. Geophys. Res., 112, D24S47, doi:10.1029/2007JD008809, 2007.

Uppala, S. M., Kålberg, P. W., Simmons, A. J., Andrae, U., da Costa Bechtold, V., Fiorino, M., Gibson, J. K., Haseler, J., Hernandez, A., Kelly, G. A., Li, X., Onogi, K., Saarinen, S., Sokka, N., Allan, R. P., Anderson, E., Arpe, K., Balmaseda, M. A., Beljaars, A. C. M., van den Berg, L., Bidlot, J., Borman, N., Caires, S., Dethof, A., Dragosavac, M., Fisher, M., Fuentes, M., Hagemann, S., Hólm, E., Hoskins, B. J., Isaksen, L., Janssen, P. A. E. M., Jenne, R., McNally, A. P., Mahfouf, J.-F., Mocrette, J.-J., Rayner, N. A., Saunders, R. W., Simon, P., Sterl, A., Trenberth, K. E., Untch, A., Vasiljevic, D., Viterbo, P., and Woollen, J.: The ERA-40 reanalysis, Q. J. Roy. Meteorol. Soc., 131, 2961-3012, 2005.

Vogelmann, A. M., Ramanathan, V., and Podgorny, I. A.: Scale dependence of solar heating rates in convective cloud systems with implications to General Circulation Models, J. Climate, 14 1738-1752, 2001.

Zhang, L., Gong, S. L., Padro, J., and Barrie, L.: A size-segregated particle dry deposition scheme for an atmospheric aerosol module, Atmos. Environ., 35, 549-560, 2001. 